\title{
Móczár József*
}

\section{Közgazdaságtan vagy közgazdaság-tudomány? I. rész}

\author{
A 20. század legfontosabb eredményei
}

A cikk alapvető kérdése: vajon tudomány-e a közgazdaságtan, és ha igen, akkor tekinthetö-e önálló tudománynak. A választ az elmúlt század legfontosabb eredményeiből kiindulva keresi. A szerző arra a következtetésre jut, hogy napjaink föáramú közgazdasági elméletei nagyrészt Ramsey, Neumann és Haavelmo munkáira vezethetők vissza. Tudománnyá válását nagyban elösegítette a matematika és a természettudományok, föleg a fizika eredményeinek alkalmazása. Mindezt Roy E. Weintraub úgynevezett történetirekonstrukciós módszerével és Lakatos Imre racionális rekonstrukciója segítségével mutatja meg. Journal of Economic Literature (JEL) kód: B23, C10, C20

Kulcsszavak: közgazdaságtan, közgazdaság-tudomány, történeti rekonstrukció, racionális rekonstrukció

\section{Bevezetés}

Úgy tűnik, hogy a globalizáció és az egypólusú világ kihívásaival nem tud mit kezdeni a közgazdaság-tudomány. A 80 -as évek végétől valójában még mindig csak a problémák megfogalmazásánál tart. Hiányoznak az új elméletek, s a mai piackonform mainstreamelméletek is bizonyíthatóan vagy Ramsey vagy Neumann vagy Haavelmo múlt század első felében született elméleteiből erednek, zeneelméleti nyelven fogalmazva, pusztán csak átiratok, hasonlóan, például Mozart Haydn-átirataihoz, amelyek új hangszerelését most Schrödinger egyenletei és Heisenberg bizonytalansági relációja adja. A közgazdaságtan statisztikai, számviteli, pénzügytechnikai stb. ismereteinek többsége is eme eredmények következményei. Ugyanakkor a közgazdasági elméletek egyik fö forrása, a társadalomfilozófia elszigetelődött, és ami felszínre tört, az is csupán csak az utilitárius liberális benthanizmus ortodox replikációja.

A szakma egyre inkább hatalmas adatbázis elemzésével az üzleti élet napi menedzselése és a corporate governance felé fordul. A piaci igényeknek megfelelően a felsőfokú képzésben

\footnotetext{
* Dr. Móczár József egyetemi tanár a Budapesti Corvinus Egyetem Matematikai közgazdaságtan tanszékén, e-mail: jozsef.moczar@uni-corvinus.hu.

A cikk a szerzö közelmúltban megjelent könyvének (Fejezetek a modern közgazdaságtudományból. Sztochasztikus és dinamikus, nem egyensúlyi elméletek, természettudományos közelítések. Akadémiai Kiadó, Budapest, 2008, 608. o.) legelső vázlatait tartalmazza. A szerző különösen hálás Csaba Lászlónak, aki bátorította e vázlatok publikálására.
} 
a pénzügyi és számviteli tanokon alapuló föiskolai business schoolok válnak meghatározóvá, s az elméletek kutatására és oktatására predesztinált egyetemi közgazdasági karok egyre jobban összezsugorodnak, a tudományos és a publicisztikai írások keverednek, a koordinátatengelyek szerepének felcserélése a dilettantizmus határát súrolja. A Nobel-díj Bizottság is egyre bizonytalanabb: honlapján a közelmúltban számos javaslat volt olvasható Bill Gates jelölésére. A régi dilemma ismét felerősödik: egy ilyen zavaros helyzetben beszélhetünk-e egyáltalán közgazdaság-tudományról?

Persze sokan vannak, akik azt vallják, hogy mindez csak a „vihar elötti csend”, a közgazdaság-tudomány gyökeres átalakulás előtt áll, és a globalizáció és a corporate governance elmélete forradalmasíthatja a közgazdaságtant. Egy ilyen átmeneti állapotban érdemes elgondolkodnunk és egyféle számvetést készítenünk azokról a fejlődési fázisokról, amelyek valós közgazdasági kérdések megoldását, de azokról is, amelyek inkább csak az öncélú tudománnyá válását segítették elö.

Az e cikkben foglaltak egy lehetséges értelmezése ennek a folyamatnak, ami természetesen vitatható, s nem feltétlenül mindenki számára elfogadható tömör rekonstrukciója a közgazdaságtan történeti fejlődésének a jelen perspektívájából. Hűen követjük a Lakatos Imre által megfogalmazott híres tézist: „A tudományfilozófia a tudománytörténet nélkül üres, a tudománytörténet a tudományfilozófia nélkül vak." E tézis első részének magyarázata röviden úgy foglalható össze, hogy minden olyan tudományfilozófia - vagyis a közgazdászok terminológiájában metodológia -, amely nem veszi figyelembe az általa vizsgált tudomány történetét, elvéti a saját tárgyát, hiszen nem ismeri meg annak valódi működését, természetét. Vagyis itt most sokkal mélyebb értelmet kap a közgazdaságtan tudománytörténete a szokásos elmélettörténeti megközelítéseknél, amelyek többnyire csak a problémák korhü társadalmi-gazdasági szempontjaira térnek ki, az adott terület modern eredményeibe történő beágyazás nélkül. Ez pontosabban azt jelenti, hogy egy-egy téma kifejtése az első, múlt századbeli érdemleges elméleteiből kiindulva el kell, hogy jusson napjaink, sőt a közeljövő várható legújabb eredményéig. A tézis második része azonban ennél jóval problematikusabb: azt állítja, hogy minden olyan történeti kutatás, amelyik nem egy filozófiai koncepció mentén halad, meddő és értelmetlen. Ezért a közgazdaságtan történetéhez azzal a filozófiai koncepcióval fordulunk - s ezzel követjük Lakatos Imre racionális rekonstrukcióját -, hogy választ kapjunk arra a kérdésre, tudomány-e, sőt önálló tudomány-e a közgazdaságtan.

\section{A modern közgazdaságtan megszületése}

A tudomány leginkább a tudománytörténeten való elmélkedés révén ismerhető meg. A közgazdaságtan számos klasszikus kérdésfelvetése a társadalommal foglalkozó filozófusok gondolataiból és a gyakorlati gazdaságpolitikai vitákból származott. Az előbbiek Arisztotelésztől, a középkori teológián keresztül a 18. századi morálfilozófiáig ívelő tradíciót testesítik meg, az utóbbiak pedig a korabeli kereskedők és tanácsadók ellentmondásos javaslatai voltak, amelyeket gyüjtőnéven merkantilizmusnak illetve kameralizmusnak neveztek. Adam Smith (1776) megfogalmazásában „a filozófia és a megfigyelés beható szelleme kiterjeszkedett a köz gazdaságára és a kereskedelemre", ami a politikai gazdaságtan megszületéséhez vezetett. Igy nem meglepő, hogy a politikai gazdaságtan Nagy-Britanniában alakult ki, amely nemcsak a kapitalizmus szülöföldje volt, de a nemzetközi kereskedelemben is 
meghatározó szerepet töltött be több mint 150 éven keresztül. A klasszikusok munkáiban is a kereskedelem állt a centrumban; például David Ricardóra többen emlékeznek a komparatív költségek előnyéről írt fejtegetései, mint a munkaérték-elmélete alapján.

Nagyjából egy évszázaddal később a kétféle megközelítés összekapcsolódása eredményezte a modern közgazdaságtant, amelyet már az egyéni racionalitás posztulátuma és a társadalmi folyamatoknak a gazdasági körforgással történő szintetizálása jellemez (vö. Mátyás 1999). A közgazdasági elméletben - amint megmutatták - a racionalitás a konzisztens magatartási preferenciák létezésén és az egyéni cselekvésben e preferenciák követésén alapul. A preferenciák matematikailag egy jól definiált hasznossági függvénnyel reprezentálhatók, ezáltal a racionális viselkedés az egyén számára azt jelenti, hogy hasznossági függvényének a lehető legnagyobb értékét igyekszik elérni, azaz hasznosságot maximalizál. A régi görögöktől a nagy kortársig és vetélytársig, Keynesig terjedő szintézisig, a neoklaszszikus paradigma kialakulásáig tartó evolúciós folyamatnak kitűnő ábrázolását adja Joseph Schumpeter magnum opusa, a History of Economic Analysis (1955) címü monumentális müve.

Az 1960-as és az 1970-es évekre az úgynevezett mainstream közgazdaságtant teljesen technikai diszciplínába transzformálták, a tudomány összes „szerszámával”. Mára pedig már az összes vezető közgazdasági folyóiratot teletömték a sokszor plauzibilis közgazdasági problémák vagy virtuális valósághelyzetek természettudományos tételekkel történő bizonyításaival, a variációszámítás és a funkcionálanalízis alkalmazott módszereivel, a játékelmélettel, a pénzügyi matematikával, a statisztikai paraméterbecslésekkel és a hipotézistesztekkel, miközben a közgazdaságtan égetően fontos kérdéseit megválaszolatlanul hagyták. Néhányan azt állítják, hogy a közgazdaságtan most jobban matematizált, mint a fizika, és a nem technikai közgazdasági írásokat gyakorlatilag kitiltották az akadémiai életből. Olyannyira, hogy egyes elmélettörténészek a mai közgazdaságtant „öncélú intellektuális játéknak" tekintik (lásd például Blaug 1998). E folyamatok valósággal tálcán kínálták a témát Weintraub (2002) sokak által vitatott legújabb, Why Economics Became Mathematical Science című könyvéhez.

Részben a neoklasszikus közgazdaságtan fizikai metaforákon alapuló kezdeti eredményein felbuzdulva, részben a legújabb problémák kutatását elősegítő saját kifejlesztésű módszertan hiányában mára a közgazdaságtan kérdéseinek vizsgálatába szinte már valamennyi természettudományos terület kutatási módszereit és legújabb eredményeit is bevonták; a szubmikroszkopikus részecskék véletlenszerű mozgását leíró Brownegyenletektől a Hawking (1998) és Penrose (1999) által matematizált fekete lyukakig, a Brüsszeleátortól a neuronhálókig, a légköri gömbvillámoktól a klónozásig. Ma már sokkal több az importált természettudományos módszer, mint a saját fejlesztésű. Mindez Neumann János azon vízióját látszik alátámasztani, hogy a közgazdaságtan - az ő értelmezésében egy lehetséges természettudomány, amely azonban még nem érte el egészen ezt a szintet.

Sokan, főként a nem közgazdász képzettségűek köréből azt gondolják, hogy a közgazdaságtannak nincsenek határai, bármely tudományterület könnyü prédája lehet. Talán még az orvostudományt mímelő sarlatánoknál is többen gondolják magukról, hogy értenek a gazdasági betegségek „gyógyításához”. A malthusi „dismal” (lehangoló) jelző helyett ma a „határtalan” (boundless) lehet a legmegfelelőbb. Maguk a professzionális közgazdászok is érzékelik ezt, és időről időre felmerül a kérdés körükben: vajon ebben a helyzetben tekinthető-e a közgazdaságtan önálló tudománynak, elfogadható-e Weintraub gyászos temetői érvelése és egyáltalán tudomány-e. 
Mostanában Alan S. Blinder fejtette ki nézeteit a közgazdaságtan tudomány voltáról az Amerikai Filozófiai Társaság ülésén, 1999. április 23-án. Fejtegetésének különös érdekessége volt, hogy megkísérelt válaszolni arra a kérdésre is, hogy vajon adott-e valami használható tudást a közgazdaságtan, vagyis „olyan elméleteket, amelyek a gyakorlatban hasznosak" (vö. Hicks 1976). A 20. században a közgazdasági diszciplínában bekövetkezett három kiugró változásra koncentrált: a matematizálásra; az invencióra, a fejlődésre és az ökonometria használatára; a makroökonómia szubdiszciplínaként történő megjelenésére. E területeknek - bár a fentiektől eltérö koordinátájú - tudománytörténeti vizsgálata különösen érdekes lehet cikkünk alapvető kérdését illetően. A közgazdaságtannak azonban csak a dinamikában megjelenő kérdéseit tartjuk relevánsnak, ezért itt most figyelmen kívül hagyjuk a statikus közelítéseket, egyetlen egy kivétellel, mégpedig Debreu értékelméletével. Célkitüzésünk, hogy bemutassuk: a mai mainstream közgazdaságtan elméletei és modelljei Ramsey, Neumann és Haavelmo elméleteiből származnak, ha úgy tetszik, azok tudományos exercise-i, átiratai. Elsősorban az alapvető közgazdasági összefüggések tudományfilozófiai bemutatása és nem a különböző technikák részletei érdekelnek bennünket.

\section{Közgazdasági elméletek, modellek redukcionális származtatásai}

A különböző tudományterületek közötti analógiák alapján történő vizsgálódásokat redukcionizmusnak nevezi a tudományelmélet. Egy tudományos eljárást pedig redukcionálisnak nevez, ha egy tudományterület alapvető tulajdonságait egy másik tudományterület metodológiája és meglévő ismeretei alapján származtatja. A tudománytörténet eddigi kutatásai szerint a standard hierarchikus redukciós séma a következő: fizika $\rightarrow$ kémia $\rightarrow$ biológia $\rightarrow$ közgazdaságtan. Ha elfogadjuk ezt a sémát (vö. Medawar 1969), akkor sem a kémia, sem a biológia és a közgazdaságtan sem formálhat jogot az önálló tudomány megkülönböztetésre. Tudományunk szempontjából viszont megjegyzést érdemel, hogy ez a séma feltételezi a klasszikus mechanika állításainak általános érvényét és a determinisztikus világnézet dominanciáját.

A determinisztikus világnézet szerint elvileg minden determinisztikus szabályokat követ. Vagy az emberi képesség, vagy a technikai korlátok akadályozzák meg az empirikus jelenségek teljes megértését. Laplace démonja egy olyan univerzális tudóst képvisel, akit nem korlátoznak ezek a technikai vagy mentális megszorítások. Egy kísérlet végtelenül sokszor történő megismétlésének hipotetikus lehetősége ugyanazzal a kimenettel lehetőséget teremt a fizikai konstansok meghatározására és a kísérlet alapjául szolgáló alapvető mozgási törvények származtatására. Mihelyt ismertek a mozgási törvények és a fizikai konstansok, lehetséges elöre jelezni a kimenetet, nemcsak azokét, amikből származnak, de a kapcsolódó és kvalitatíve hasonló eseményekét is általános értelemben. Ha a tudomány nem volna képes a fizikai folyamatok kimenetelének pontos előrejelzésére, akkor a 18. és a 19. században tett nagy felfedezések sem következtek volna be, és a fizikának egyáltalán semmilyen hatása sem lett volna a többi tudományterületre, köztük a közgazdaságtanra sem.

A determinisztikus világnézet és az attitűd az előre jelezhetőség megoldására a 19. századtól kezdve befolyást gyakorolt a politikai gazdaságtanra is. A Laplace-iállítás közvetlen adaptálása az emberi magatartás előrejelzésére azt implikálja, hogy szabad emberi akarat egyáltalán nem létezik, és ezt az elgondolást valamiféle rejtett módon a filozófiai gondol- 
kodás testesítette meg. Hegel történetfilozófiája és később Marx determinisztikus gazdasági és társadalmi fejlődéstörvényei jelzik, hogy a 19. század folyamán egyféle igény jelent meg, hogy összehasonlítsák az emberi tevékenység átfogó hatásait a mozgás kvalitatíve ugyanazon törvényeivel, amelyeket a természettudományokra alkalmaztak. A klasszikus fizika, másként a mechanika determinizmusa, az idealista filozófia, vagy a marxi szociológia kezdte helyettesíteni az emberi élet isteni predesztinációjának teológiai képét.

Ha nincs szabad emberi akarat, akkor lehetséges általánosítani az egyéni emberi magatartást, és elvonatkoztatni az izolált emberi értelmen alapuló szinguláris jelenségektől. Ezért lehetőség van arra is, hogy az egyén cselekedeteit tipikus viselkedésminták szerint írjuk le, feltéve, hogy patológiai attitüdök a realitás irányában nem jellemzik. Az elgondolás, hogy az egyének bizonyos fokig tipikus minták szerint viselkednek, lényeges premissza a közgazdaságtan tudománnyá válásában. A gazdasági viselkedés tipikus mintáit egy meglehetősen egyszerű közelítés segítségével vezették be a közgazdaságtanba: egy tipikus szereplő racionalitása egy adott környezetben predeterminált hasznossági függvény maximalizálásából áll, ami nélkülözi a pszichológiai és a szociológiai megfontolásokat. Amit később a közgazdaságtan axiomatikus megalapozásának neveztek, alapvetően semmivel sem több, mint a fundamentális magatartási törvények hipotetikus determinációja, amiből a közgazdasági állítások tautologikusan következnek, bár általában nem evidensen.

A hipotézisek szerinti fundamentális magatartási minták e determinációja körvonalazta az egyéni cselekvés tanulmányozásának alapvető problémáját egy gazdaságon belül, és megtisztította az utat egy pontos közgazdaságtan felé, abban az értelemben, hogy a gazdaság viselkedése a környezet gondos leírásával - bár közgazdasági konstansok nélkül, de - egyértelmü kimenetekre vezet. Ez a fajta közgazdaságtan már erős hasonlóságot mutat a klasszikus fizikával, mint a 18. és a 19. század legfejlettebb tudományával. Ez a fajta hasonlóság a klasszikusok munkáira a 19. század közepéig, kevésbé volt jellemző, és csak a század második felében elterjedt matematikai formalizációval vált lehetővé, hogy a közgazdaságtan az emberi élet problémáinak megoldására vagy mint a fizika, vagy mint a matematika alkalmazása jelenjen meg a fizikával ekvivalens státusban. A modern matematikai közgazdaságtan elöfutárai, Walras, Jevons és Pareto nemcsak tudatában voltak a hasonlóságnak, de terjesztették is a fizikai módszerek használatát a közgazdaságtanban. Walras állandóan azt hajtogatta, hogy a közgazdaságtant a fizikához hasonlóan kell strukturálni, és azt állította, hogy már a klasszikusok is erre törekedtek. Ugyanakkor Marshall arra hívta fel a figyelmet, hogy a természettudományok közül nem a fizika, hanem a biológia az, amelyik szorosan analóg a közgazdaságtannal, Menger pedig a határhaszon fogalmát már egyenesen a pszichológia szempontjából értelmezte.

A determinisztikus világnézet idilli állapotának az elmúlt századfordulón a kvantummechanika és valamivel később a relativitáselmélet eredményei vetettek véget. Világossá vált, hogy a klasszikus mechanika csak a közelítését képes adni azoknak a jelenségeknek, amelyek történetesen megjelentek az emberek által megfigyelhető pillanatnyi skálán. Heisenberg kvantummechanikája a bizonytalansági relációval, és Schrödinger egyenletei azt mutatták, hogy a legjobb, ami ebben a helyzetben tehető, a lehetséges jelenségek sztochasztikus leírása. Elméletük szerint a valóságnak csak a sztochasztikus leírásai tekinthetők értelmes közelítésnek a fizikai jelenségek magyarázatában. A fizika mellett „anyatudományként” megjelent az evolúciós biológia (Samuelson 1947), a pszichológia (Simon 1957), majd a biokémia is (Prigogine 1983). Míg a determinizmus a matematikai közgazdaságtan fejlődésének volt a lámpása, addig az indeterminizmus az ökonometria kialakulásához vezetett. A kétféle 
megközelítés egészen napjainkig számos közgazdasági modellt eredményezett, nem zárva ki az egymás közötti átjárás lehetőségét sem, sőt azokat a meglepő eredményeket sem, hogy determinisztikus modellek is eredményezhetnek sztochasztikusan viselkedő idősorokat. Például Stanislaw Ulam, Neumann János (1942) és később Edward Lorenz (1972) bizonyos paraméterértékek mellett a változók véletlenszerü viselkedését fedezték fel determinisztikus modelljeikben. Az újklasszikus makroökonómia pedig, hogy megfeleljen a sztochasztikus kihívásnak, az alapvetően determinisztikus lineáris dinamikus összefüggésekbe Haavelmot követve - egyenesen sztochasztikus exogén változókat vezetett be.

A továbbiakban megvizsgáljuk a klasszikus mechanika, a matematika és a statikus mechanika azon redukcióit, amelyek a modern elméleti (matematikai) közgazdaságtan kialakulását és az ökonometria, az alkalmazott közgazdaságtan megszületését eredményezték. A biológia és kémia lehetséges közgazdasági redukcióit illetően is komoly kutatások folynak, de markáns eredményekről még nem számolhatunk be.

\section{A neoklasszikus közgazdaságtan genezise}

A közgazdász többsége azt gondolja, hogy a 19. század utolsó harmada kulcsszerepet játszott tudományunk fejlődésében. Mindez azzal magyarázható, hogy a korabeli klasszikus közgazdasági gondolkodásban egyféle diszkontinuitás, ${ }^{1}$ de legalábbis fejlödési megtorpanás mutatható ki az 1870-es és az 1880-as években, ami lehetővé tette a 19. század közepi matematikai fizika fejleményeinek behatolását az akkori politikai gazdaságtanba, és ami elindította a „marginális forradalmat”. ${ }^{2}$ A marginalista diskurzus előbb a politikai gazdaságtant közgazdaságtanná transzformálta, majd később a közgazdaságtant modern tudománnyá fejlesztette. Amint Mirowski (1984) megjegyezte, „a fizikai metafora alkalmazása az elfogadott tudomány szavahihetőségét biztosította a közgazdaságtannak", ami lényegében Neumann (1955:15) replikációja: „Ha tehát felfedezzük, hogy az egyik terület nehézségei által szükségessé tett elmélet helyesen ír le dolgokat más területeken is, ennek nagy a meggyőző ereje."

A neoklasszikus közgazdasági elmélet kemény magjaként a 19. század közepi fizikát adaptálták, ez az az alapeszme, amit merev paradigmaként megőriztek - kisebb-nagyobb koncepcióváltásokkal - mindvégig a 20. század folyamán és még azután is, hogy a fizika új metaforák és új technikák irányába fordult. Mindez azt is jelentette, hogy rivális paradigmák hiányában Kuhn (1970) legtöbbet vitatott tézise, az inkommenzurabilitás nem játszott szerepet, azaz a tudományos terminusok és a döntési szempontok végig azonosak voltak, az összemérhetetlenség kérdése fel sem merülhetett. ${ }^{3}$

\footnotetext{
1 Néhányan tagadják ezt a megállapítást, például Bowley (1973) szerint Adam Smith-től napjainkig folytonos diszciplínát alkot a közgazdaságtan. Hasonlóképpen vélekedik Blaug (1978:322) is: „nem történt hirtelen változás, csak fokozatos átalakulás". A közgazdasági marginalizmus kialakulása szempontjából természetesen ez teljesen érdektelen.

${ }^{2}$ Hicks (1976) szerint a "marginalista” jelző félrevezetö lehet, ugyanis a 'határ' (margin) nem adekvát a maximum (vagy a minimum) matematikai szabályával; amennyiben maximalizálásról van szó, akkor minden közgazdász marginalista. Ezért a 'katallakszista' terminust használja.

3 A neoklasszikus iskola ellenzéke az institucionalizmus alakjában jelentkezett, amely az 1920-as évek alatt fejlödött ki Amerikában, és Wesley C. Mitchellt tartotta akkor a vezetőjének. Wesley C. Mitchell és Carl Snyder, valamint olyan prominens teoretikusok, mint J. M. Keynes, Irving Fischer és Charles Rist (vö. Frisch 1932) ugyan hevesen ellenezték a neoklasszikus iskola tanításait, de a matematikai és statisztikai módszerek alkalmazásával egyetértettek.
} 
Amint a klasszikus közgazdaságtant Adam Smith formálta összefüggő rendszerré, úgy a marginális forradalom eredményeiből - Wicksell közvetítésével - Alfred Marshall szerkesztett egységet. A marginális közelítés a klasszikus közgazdasági elméletek kínálatorientált (termelési) szemlélete helyett a keresleti (fogyasztási) tényezők hatását emelte ki. A homo oeconomicus értelmezésével, aki fogyasztási döntéseit a margináliákon hozza és a jószágok értékelését a szubjektív értékelmélet alapján végzi, jelentősen hozzájárult a neoklasszikus közgazdasági paradigma megszületéséhez.

A korai neoklasszikus közgazdasági elmélet alapjait a 19. század közepi fizikából vették át; két kedvenc metaforájuk a nyomaték egyensúlyának racionális mechanikája és az égitestek közötti matematikai viszonyok voltak. A hasznosságot úgy definiálták újra, hogy az az energiával legyen azonos. Mirowski (1984) kutatásai azt igazolják, hogy Walrasnál nyoma sincs a fizikai metafora megértésének, és a matematikai technikákat és a metaforát is mechanikusan és fantáziatlanul alkalmazta. Jevons még kevésbé volt matematikus; leginkább az energetikai metafora gazdasági jelentésére koncentrált. Marshall volt az, aki értette is az energetikai metaforát, aki szerint a fizikai interpretáció elválasztható a matematikai technikától, és fenntartásai inkább az interpretációra, semmint a technikára vonatkoztak. Éppen ezért nála a matematika kapott nagyobb szerepet, annak tagadásával, hogy az befolyásolhatja a mondanivalót.

Kutatási módszertana többnyire már a tisztán elméleti, deduktív érvelés volt, ami azon a formális logikai tételen alapult, hogy igaz feltevésekből érvényes műveletek közbeiktatásával mindig igaz következtetésre jutunk. Másképpen, a matematikai dedukció pusztán egyfajta logika, nevezetesen az elméleti szükségszerüség logikája. Ez éppen az inverze volt a klasszikusokénak, többek között John Stuart Mill (1806-1873) nézetének, aki szerint a matematika empirikus tartalmát az induktív empirikus általánosítások adják a teljes logikai szerszámos láda felhasználásával, és az evidenciák lényeges része empirikus és számláláson alapul. A korai neoklasszikusok ugyanis észrevették, hogy Mill elmélete képtelen megmagyarázni, hogy a $2+3=5$ kijelentést miért tartjuk nemcsak igaznak, hanem szükségszerűen igaznak és teljes mértékig bizonyosnak, sőt akár a látszólag ellentmondó empirikus evidencia ellenére is megcáfolhatatlannak (vö. Harsányi 1983). Mill indukciós elmélete egyébként is meglehetősen korlátozott volt, mivel William Whewellel (1794-1866) szemben nem engedte meg a nem megfigyelhető tulajdonságokra és objektumokra vonatkozó következtetéseket (bővebben lásd Snyder 1997). „Levelezésükben és közzétett műveikben a korai neoklasszikus közgazdászok egymásra mindenekelött matematikai gondolkodókként tekintettek; amikor tanításaikat hirdették, azt rendszerint a közgazdasági elmélet kontextusában a 'matematikai módszer' védelmének köntösébe öltöztették." (Mirowski 1984: 200.)

A logicista filozófusok (elsősorban Gottlob Frege és a fiatal Bertrand Russell) szerint a matematikai axiómák bizonyossága a logikai intuícióból származik. Ez azt jelenti, hogy a matematika axiómái logikailag igaz állítások, tagadásuk pedig önellentmondás. Ekkor a matematika tételeinek igazsága ugyanabból a forrásból táplálkozik, mint a matematikai bizonyítások helyessége, vagyis a logikából, ami viszont szoros kapcsolatban áll a gondolkodás alapmüveleteivel, vagyis megkérdőjelezhetetlen. A matematika tehát - mint állították - tévedhetetlen tudomány.

A logicista program kudarca azonban csakhamar megmutatkozott, és a sors iróniája, hogy éppen a leglelkesebb képviselöje, Russell tapintott rá egy olyan pontra, amely a fregei rendszer tarthatatlanságára világított rá. A Russell-paradoxon (1902) és a Cantor, illetve Burali-Forti által már korábban felfedezett egyéb halmazelméleti antinómiák ismertté 
válása világossá tette, hogy Frege programjának kivitelezése, nevezetesen az aritmetika (és erre támaszkodva a valós számok elmélete) fogalmainak és tételeinek megalapozása logikai, illetve ismeretelméleti analízis révén egyáltalán nem triviális feladat. Az a logikai intuíció, amelyre a matematikát vissza akarták vezetni, és amelyet a naiv halmazelmélet foglal fogalmi keretbe, menthetetlenül ellentmondásos. Az ellentmondásokat ugyan ki lehet küszöbölni egy axiomatikus halmazelmélet segítségével, ez a lépés azonban már a logicista program elárulását jelenti: a halmazelmélet axiómáit sokkal kevésbé támasztja alá bármilyen logikai intuíció, mint például az aritmetika axiómáit, vagyis a matematika alaptételeinek igazolásához ez az út nem bizonyult járhatónak. Russel paradoxona - Frege szavaival - „aláásta a matematika egészét". Russel megpróbálta kijavítani a hibát, és visszahelyezte a matematikát logikai alapokra a Whiteheaddel közösen írt Principia Mathematica címü könyvükben. A mü tulajdonképpen logikai alapokra redukálta a matematikát, és rendkívüli befolyással volt a matematika fejlődésére.

Ugyanakkor a századfordulón éles viták folytak a közgazdaságtan tudományok közötti helyéről, olyannyira, hogy a német történeti iskola, az amerikai institucionalisták, az osztrák iskola és még több más áramlat képviselői is kétségbe vonták tudományos jellegét. Valamelyest enyhít ezen a (há)borús képen, hogy hasonló viták zajlottak le a matematika és a fizika fejlődését illetően is, ami három fö kérdés tisztázását tüzte ki célul: (1) az eukleidészi geometria kudarcát a nem eukleidészi geometria befogadására; (2) a halmazelmélettel kapcsolatos problémák, amelyeket Georg Cantor „végtelenen” alapuló eszméi világítottak meg; (3) az aritmetika és a logika alapjaiban lévő paradoxonok, amelyek felfedezését Gottlob Frege és Guiseppe Peano nevéhez kapcsolják. Mindez a tiszta matematika új eszméinek kutatásához vezetett, amelyek a következők:

- a végtelen halmazok elméletének kidolgozása [Georg Cantor (1845-1918)];

- Félix Klein (1849-1925) bejelentése 1872-ben az úgynevezett Erlangen Programról, amely a geometriát a transzformációs csoportok mellett az invariáns absztrakt objektumok tanulmányozására ösztönözte;

- 1899-ben megjelent David Hilbert Grundlagen der Geometrie címü müve, amely axiomatizálja a geometriát.

Mindhárom eszme Németországból indult el, s rövid idő alatt jelentős változásokat eredményezett mind a matematika többi tudományághoz való viszonyában, mind pedig a matematikai gondolkodásmód fejlődésében. A kiváltott sokkhatás egészen az 1930-as évekig tartott, ami végül is azt eredményezte, hogy a matematika levált a többi természettudományról és az önálló fejlődés útjára lépett.

Annak felismerése, hogy a halmazelmélet és a logika paradoxonjai összefonódtak, vezette a matematikusokat a 20. század elején ahhoz, hogy új alapokat keressenek a matematika axiomatizálására és a halmazelmélet, a logika és az aritmetika megalapozásának formális modellezésére. Az 1920-as, 1930-as évekre a matematika ismét világossá és koherenssé vált. Ahhoz, hogy vizsgálhassuk a közgazdaságtan átalakulását is, elsősorban ezt a matematikai átalakulást kell tanulmányoznunk, hogy megértsük, hogyan formálódott át a modern közgazdasági elmélet „magva” matematikai diszciplínává a 20. század első kétharmadában, vagyis hogyan alakult át a matematikai közgazdaságtan a mai formájába, hogyan születtek meg a modern közgazdasági elméletek. 


\title{
Matematikai közgazdaságtan Ramsey, Bentham és Wittgeinstein prizmáján keresztül
}

\author{
„A matematika egy nyelv" - Willard J. Gibbs
}

A 20. század elmélettörténészei szinte már kötelező konvenciónak tartják eszmetörténeti munkáikban, hogy szembeállítsák a pluralisztikus, két háború közötti időszak közgazdaságtanát a monolitikus (neoklasszikus) háború utáni közgazdaságtannal. Ez a fajta megközelítés két egymásnak ellentmondó metanarratívát eredményezett. Az első arról az erkölcsi progresszióról számol be, ami végül is elvezetett ahhoz, hogy a közgazdaságtan beváltotta a jevonsi ígéretét és tudomány lett a matematika és a statisztika használatán keresztül. Jevons egészen pontosan úgy érvelt, hogy „a közgazdaságtan csak akkor tud fokozatosan egzakt tudománnyá válni, ha a jelenleginél sokkal szélesebb körüvé és pontosabbá válik, és így az összefüggések a számszerü adatok segítségével egzakt tartalmat nyerhetnek". (Részletesebben lásd Samuelson 1970.) A másik rekonstrukció szerint a két háború közti időszakban a közgazdasági gondolkodás egészséges pluralizmusát a neoklasszikus elmélet Prokrusztész-ágyába kényszerítették, és „,ami ezáltal előállt a neoklasszikus szintézis idejére, az egy örömtől, intelligenciától és humanitástól megfosztott közgazdaságtan” lett. Ez utóbbi nézet képviselőiként Weintraub (2002) a modern institucionalistákat, a neoosztrákokat és a posztkeynesianusokat jelöli meg. Mindkét metanarratíva esetében ugyanaz a kérdés: „Miért váltotta fel a neoklasszicizmus a pluralizmust?” És a két meseszerü metaválasz: "Azért, hogy a jóság diadalmaskodjék”, illetve „Azért, hogy az ördög diadalmaskodjék." Mindkét metanarratíva azonban osztotta azt a nézetet, hogy a matematikai eszmék kiszorították a nem matematikai elmélkedést a közgazdaságtanból.

Nicholas Georgescu-Roegen (1971:3) még ennél is tovább megy, amikor a közgazdasági gondolkodás történetében különös eseménynek tekinti azt a folyamatot, hogy ,évekkel azután, hogy a mechanisztikus dogma elveszítette az uralkodó pozícióját a fizikában és szorítása enyhült a filozófia világán, a neoklasszikus iskola alapítói a mechanika mintájára fogtak hozzá a közgazdaságtan tudományának kimunkálásához, ami Jevons szavaival „a hasznosság és az önérdek mechanikája" (Jevons 1924:21). S bár a közgazdaságtan nagyot fejlődött, semmi sem történt annak érdekében, hogy a közgazdasági gondolkodás szakítson a standard közgazdaságtan ősatyáinak gépies módszertanával. „Azt a nyilvánvaló tényt, hogy a gazdasági folyamat és az anyagi környezet között folyamatos kölcsönhatás létezik, egyáltalán nem veszik figyelembe a standard közgazdaságtanban. (...) Marx híres újratermelési diagrammjában is körfolyamatként és teljesen önfenntartó rendszerként jelenik meg a gazdasági folyamat." Ami a neoklasszikus közgazdaságtan gépies módszertanát illeti, igazolva látjuk Georgescu-Roegen ezen megállapítását fizikai realitásában is, ha Jevons „logikai pianínójára”, Irving Fischer közlekedő edényrendszerére vagy az újabb időkből Arnold Phillips szemléltető eszközére gondolunk, de más iskolákat is „megfertőzött”, mint például a keynesianus Richard H. Goodwint, aki az IS-LM modellre épített meg egy szemléltető eszközt.

A szubjektív hasznosságelmélet beépülése a közgazdaságtanba viszont már oly mértékben előrehaladt, hogy sem Volterra, sem tanítványa, Griffith Conrad Evans nem 
tudta feltartóztatni továbbterjedését, ami végül is Evans marginalizációjához vezetett. ${ }^{4}$ Frank Plumpton Ramsey (1928) megússza, mivel ő - a valószínűség-számításban elért eredményei és a liberális utilitárius benthanizmus alapján - el tudta fogadni a hasznosság maximalizálását, sőt csak ezt tudta elfogadni, de elmélete túlságosan matematizált volt ahhoz, hogy eljusson a közgazdászokhoz.

Frank Plumton Ramsey (1903-1930) matematikát tanult Cambridge-ben, majd tanulmányai befejeztével ugyanott tanított matematikát. Az első jelentősebb munkáját 1925-ben publikálta The Foundations of Mathematics címmel. Ebben elfogadta Russelnek és Whiteheadnek a Principia Mathematicában tett azon kijelentésüket, hogy a matematika része a logikának, de javasolta elhagyni az úgynevezett redukciós axiómát (a matematika logikára történő redukcióját) és kiszürni néhány szemantikai paradoxont. A Mathematical Logic címü tanulmányában élesen kritizálta Hilbertet, amiért a matematikát a formális szintaktikai kalkulusaival egy „papírra vetett jelekkel folytatott értelmetlen játékra” kísérelte meg redukálni. A matematika mellett kedvenc területe a filozófia volt: számos értékes filozófiai tanulmányt írt, de írásait beárnyékolták Wittgeinstein hozzájárulásai, de ugyanez fordítva is elmondható, bár különböző mértékben. Ramsey segítette lefordítani Wittgeinstein Tractatus Logico-Philosophicus címü müvét, és amikor Wittgeinstein 1929-ben visszatért Cambridge-be, hogy folytassa a PhD-tanulmányait, Ramsey-t jelölték ki mellé témavezetőnek. Számos ponton megbírálta, aminek érvényességét maga Wittgenstein is elismerte a Philosophical Investigations címü müvének előszavában.

Ramsey-nek különös szakmai érdeke füződött Wittgeinstein Tractatusának tanulmányozásához. Abban az időben ugyanis mint matematikust elsősorban olyan kérdések izgatták, hogy mi a matematika, miért hasznos a természet leírásában, miben különbözik a többi diszciplínától, és, különösen, mi teszi a matematikai igazságokat igazzá? Abban az időben (és még ma is) több különböző, egymással versengő válaszokat adtak ezekre a kérdésekre. Russel és Whitehead nézete az volt, hogy a matematika egyszerüen a logika kifejtése, és a logika az, ami igazzá teszi a matematikai igazságokat. Ezt próbálták bebizonyítani monumentális munkájukban, a Principia Mathematicában, amelyet három kötetben adtak közre 1910 és 1913 között, és amelyben a matematika egészét tisztán logikai elvekből származtatták. Elméletük azonban hamarosan komoly nehézségekbe ütközött, és ennek gyökerét Ramsey abban látta, ahogyan Russel közelítette a matematikát, vagyis hogy tisztán logikai kifejezésekben megfogalmazható propozíciókból állónak tekintette, mégpedig az összes dologra és összefüggésre vonatkozó teljesen általános propozíciókból. Ramsey szerint viszont nem minden propozíció matematikai vagy logikai. Ennek magyarázatául a következő példát veszi: „bármely két tárgy legalább 30-féleképpen különbözik egymástól”, ami egy teljesen általános propozíció, és ami lehet igaz is. De nem tekinthető matematikai vagy logikai igazságnak; tökéletesen különbözik attól, hogy „bármely két dolog bármely két másik dologgal együtt négy dolgot tesz ki”, ami logikai és nem csak empirikus igazság.

\footnotetext{
${ }^{4}$ Itt érdekesek lehetnek Theiss Ede tudományos munkái, amelyek - a korabeli hazai ökonometriai és matematikai közgazdaságtant képviselve - az akkori (és ma is) legrangosabb nemzetközi matematikai-közgazdasági folyóiratokban jelentek meg. Levelezésben állt sok kiváló tudóssal, többek között Ragnar Frischssel és Henry Schultzzal, az elnyert hároméves Rockefeller ösztöndíjával számos amerikai egyetemen kutatott, többek között Chicagóban, később hosszabb-rövidebb időt töltött különböző egyetemeken Svédországban és Angliában is. Angol, német és magyar nyelvü tudományos dolgozatai olvasásával nemcsak arról győződhetünk meg, hogy kutatási eredményei, nemzetközi öszszehasonlításban is, a statisztika és a matematikai közgazdaságtan frontvonalába helyezték Theiss professzort, de egyedülállóan értékes professzionális kortárselemzést is kapunk tőle a 20. század első felének neoklasszikus közgazdaságtanáról, a kibontakozó matematikai közgazdaságtan legizgalmasabb kérdéseiről.
} 
De akkor mi a logikai igazság? A Principia Mathematica erről nem mondott semmit. A Tractatus viszont igen: a logikai igazság tautológia, azaz durván fogalmazva, olyan propozíció, ami igaznak bizonyul, és semmiképp sem más propozíció bizonyul igaznak. De nem az összes tautológia matematikai igazság: a „vagy esik, vagy nem” tautológia, mivel igaznak bizonyul, bármilyen is az időjárás, de nem matematikai igazság, mert ahhoz nem eléggé általános. Ugyanakkor, a „bármely két tárgy legalább 30-féleképpen különbözik egymástól” elég általános, de mégsem mondható matematikai igazságnak, mert nem egy tautológia. Ramsey szerint egy matematikai propozíciónak mindkettőnek kell lennie: teljesen általánosnak a tartalomban, és tautologikusnak a formában. E szerint mind Harrod (1939), mind Domar (1946) olyan tautológiát fedeztek fel és fogalmaztak meg növekedési modelljeikben, amelyek matematikai propozícióknak is tekinthetők? A válasz, igen.

Egy másik terület, amelyben Ramsey megpróbált javítani a korábbi elméleteken, a valószínűség-számítás volt. John Maynard Keynes 1921-ben publikálta a Treatise on Probability címü könyvét, amelyben a valószínüséget úgy értelmezte, mint propozíciók közötti 'parciális következmény' logikai relációjának mérését, ami a priori meghatározható, és ami megmondja, hogy egy tudományos hipotézisre adott induktív bizonyitásunk milyen mértékben támasztja alá a hipotézist. Értelmezését később elfogadta a híres matematikai filozófus, Rudolf Carnap is, aki az induktív logika alapjává tette azt az 1950-ben megjelent Logical Foundations of Probability címü könyvében. Ramsey azonban elégedetlen volt vele, ellenvetései oly meggyőzőek és áthatóak voltak, hogy maga Keynes hagyta el azt. Ramsey alapvető ellenvetése az induktív logika egész elméletére vonatkozott; amit nyilvánvalónak nevezett, az az, hogy semmi olyan dolog nem látszik benne, amiket Keynes valószínüségi relációi leírnának.

A Truth and Probability címü tanulmányában abból a tényből indul ki, hogy az emberek cselekedeteit elsősorban az határozza meg, hogy mit hisznek, és mit kívánnak - és azon hitek és kívánságok erőssége. Az emberek hitének erősségét az úgynevezett szubjektív valószinüséggel mérik, amit az eseményekhez kapcsolnak. Amikor az emberek azt mondják például, hogy valószínűleg esni fog, akkor erősebben hiszik azt, hogy esni fog, mint hogy nem fog esni. De hogy mit tesznek e hit eredményeként - például, vajon visznek-e esernyőt, amikor kimennek a szabadba -, attól is függ, hogy mit akarnak: vajon el akarják-e kerülni, és mennyire, hogy vizesek legyenek; vagy másképpen, az úgynevezett szubjektív hasznosságtól, amit ahhoz kapcsolnak, hogy szárazak maradnak. A szubjektív hasznosság méri az emberek kívánságainak erősségét, éppúgy, mint a szubjektív valószinüség a hitük erősségét. A kérdés az, hogy hogyan szeparáljuk az emberi cselekedetek eme két okát. Ramsey tanulmánya megmutatta, hogyan szürjük ki az emberek szubjektív hasznosságait és valószínüségeit azon döntéseikből, amelyeket különböző kockázatos vállalkozások közötti választáskor hoznak; és ezek a fogalmak alapul szolgálnak a közgazdaságtanban, a statisztikában és a filozófiában végzett különböző elemzésekhez. Eredményeinek tükrében így már teljesen világos, hogy Ramsey miért vette a fogyasztáshasznosságot maximum célfunkcionálként $A$ mathematical theory of savings címü tanulmányában.

Ramsey egyik említésre méltó hozzájárulása a közgazdasági elmélethez Sraffának nyújtott segitsége a The production of commodities by means of commodities címü könyve megírásában. Ramsey öntötte Sraffa ricardói eszméit megfelelő matematikai formulákba. Ramsey azonban 1930-ban meghalt, így nélküle Sraffának több mint 30 évre volt szüksége, hogy megértse a modellt, és befejezze a könyvét. Ezért nem véletlen, hogy könyve előszavában köszönetet is mondott Ramsey-nek. 
Egy másik érdekes anekdota Harrod (1930) azon cikkével kapcsolatos, amelyben bevezette a marginális bevételi görbe fogalmát, és amelyet az Economic Journalhoz nyújtott be közlésre 1928-ban. Keynes mint szerkesztő Ramsey-t kérte föl a cikk bírálatára, aki tett néhány kifogást. Harrod gyenge egészségi állapota és egyetemi elfoglaltsága miatt csak 18 hónappal később vette elő a cikket, és konzultált Ramsey-vel, aki ezután visszavonta korábbi ellenvetéseit. A cikk így csak 1930 júniusában jelenhetett meg. Mindezért nagy árat fizetett Harrod, ugyanis Joan Robinson Economics of Imperfect Competition címü, korábban publikált cikkében szintén tárgyalta a marginális bevételi görbe fogalmát, és így az elsőbbség őt illette meg (vö. Harrod 1972:186). A közöttük folyó konzultáció mindenesetre arra is utalhat, hogy Harrod jól ismerte Ramsey logikai igazságról vallott felfogását, ami egyébként tükröződik is a növekedési elméletében.

Annak ellenére, hogy „lerombolta” mások munkáit, az emberek mégis szerették őt, mert magatartását nem fütötte személyes ambíció vagy a jó néhány mai tudósra jellemző arrogancia. Hasonlóképpen vélekedett róla Keynes is, annak ellenére, hogy a Treatise on Probability címü munkáját valósággal ízekre szedte (éppenséggel néhány szerző ezt tekinti Ramsey első közgazdasági hozzájárulásának). Keynes azonban nagyon civilizált ember volt, és amikor találkoztak, azonnal felismerte, hogy egy géniusszal van dolga. Keynes nyitotta meg a King College kapuit Ramsey előtt, neveztette ki munkatársnak 1924-ben és matematika előadónak 1926-ban. Néhány cinikus kritikusa úgy vélekedik, hogy Keynes egyik fö hozzájárulása a közgazdasági elmélethez az volt, hogy rábeszélte Ramsey-t, dolgozzon közgazdasági problémákon. Keynes Ramsey két cikkének publikálásához járult hozzá az Economic Journalban, amelynek akkor ő volt a szerkesztője és hihetetlenül szigorú volt a közlési kritérium.

Ramsey (1927) első közgazdasági tárgyú cikke, A contribution to the theory of taxation ma is az egyik mérföldköve a modern közösségi közgazdaságtannak. Samuelson volt az, aki ismét felfedezte és újraélesztette az irodalom számára 1951-ben, egy, az USA kincstárának készített feljegyzésében, amit később, 1986-ban publikált. Ramsey tanulmányának célkitüzése a termelékenységi hatékonyság elemzése adórendszerrel együtt, de az elosztási hatások figyelembevétele nélkül. A problémát a jövedelemkorlát melletti társadalmi jóléti függvény maximalizálásaként fogalmazta meg. Eredményül az úgynevezett Ramseyszabályt kapjuk, amely azt állítja, hogy az optimális adórendszernek olyannak kell lennie, hogy mindegyik jószág kompenzált kereslete ugyanolyan, az adózás előtti helyzet szerinti arányban csökkenjen.

Ramsey (1928) második és sajnos egyben utolsó közgazdasági témájú cikke, $A$ mathematical theory of savings egy mestermü. A tanulmány eszmei mondanivalóját Keynes indítványozta: több megtakarítás ma több fogyasztást implikál holnap. Tehát szembe kell állítanunk a mai fogyasztásunk elhalasztásának költségét azzal a haszonnal, amit annak a holnapi elfogyasztásával élvezünk. Ez a Keynes-Ramsey-szabály, ami az opportunity cost (lehetőségköltség) első megfogalmazásának is tekinthető. A Keynes-Ramsey-szabály hamarosan az aranykori tökefelhalmozás központi része lett, a modell pedig kiindulópontként szolgált Samuelson együtt élő nemzedékek modelljének (overlaping generations model), a Dorfman, Samuelson és Solow turnpike elméletének, a DOSSO-modellnek, vagy bizonyos értelemben Solow neoklasszikus növekedési modelljének, valamint az optimalizáló reprezentatív ügynök modellnek, amelyeket azután sorra követtek a különböző szerzők további „exercise”-ai vagy átiratai egészen napjainkig. Vagyis hihetetlen karriert futott be, jóllehet ehhez olyan elmék kellettek, mint Koopmans, Cass, Samuelson, Solow 
stb., akik képesek voltak felfogni a modell kisugárzását, ${ }^{5}$ illetve meglátni a modell lenyügözően gazdag közgazdasági tárházát. E tekintetben Ramsey modellje érdekes párhuzamba állítható Neumann János növekedési modelljével.

Ramsey tanulmányának erőssége közgazdasági intuíciója. Az irodalomban azonban közel 35 évet vett igénybe, amíg a közgazdászok megértették Ramsey üzenetét. Ez akkor következett be, amikor sok évvel később Edmund S. Phelps (1961) ugyanazt a kérdést tette fel, mint Ramsey: mi az optimális megtakarítási ráta egy gazdaság számára? Eljárása a lehető legegyszerübb volt. A szokásos jelölésekkel vette a $C=Y-C$ egyenletet. Mivel $S=s Y$, ezért $C=Y-s Y$, amelyet végigosztva $L$-lel és véve $Y / L=y=f(k)$ helyettesítéseket, kapjuk:

$$
c=f(k)-s f(k),
$$

ahol $s$ a megtakarítási határhajlandóság, $c=C / L$ és $\mathrm{k}=\mathrm{K} / \mathrm{L}$. Az egyenlet csupán azt állítja, hogy az $y=f(k)$ és $i=s f(k)$ görbék közötti különbség az egy före eső fogyasztást, a $c$-t mutatja. Phelps indítványozta, hogy tekintsék döntési változónak az $s$-t és az egy före jutó fogyasztást maximalizálják az $s$ megválasztásával [és így $i=s f(k)$ görbével] úgy, hogy a tartós állapotú növekedéssel - ami következik a fentiekből (ahol $i=i^{*}$ ) - fogjuk biztosítani, hogy örökké a lehetö legnagyobb lesz egy före jutó fogyasztásunk.

A kikötés az, hogy tartós állapotban vagyunk, azaz $s f(k)=n k$ (nincs technikai változás). Így a $c=f(k)-n k$ fogyasztást kívánjuk maximalizálni. Az elsőrendű feltétel a maximumhoz:

$$
d c / d k=f^{\prime}(k)-n=0 .
$$

Másképpen fogalmazva, az optimális $k^{\star}$-ban vagyunk, amikor a tartós állapot, $k^{\star}$ olyan lesz, ahol $f^{\prime}\left(k^{*}\right)=n$. Ha az $f^{\prime}\left(k^{*}\right)$-t a tőke hozadéki rátájaként értelmezzük, és az $n$-t a természetes növekedés ütemének vesszük, akkor az $f^{\prime}\left(k^{*}\right)=n$ ekvivalens az $r=g$-vel, azaz Neumann (1937), Allais (1943) és Robinson (1962) „aranyszabály”-növekedési feltételével. Phelps modellje tehát valamilyen szinten közös keynesiánus platformra helyezte Neumannt, Allaist és Robinson asszonyt.

Egy ideig úgy is tünt, hogy Phelps (1961) modelljével a hasznossági iskola elveszítette vezető helyét az optimális növekedés elméletében. A válasz azonban nem késett sokáig: elsőként Koopmans (1963), majd Cass (1965) fedezte fel újra Ramsey modelljét, és tette érthetővé a közgazdászok számára is. Az utóbbi szerző mindezt már a „szerszámos láda” új matematikai eszközével, az optimális irányítás felhasználásával teszi, amit az 1950-es években fejlesztett ki Pontrjagin (1968) a munkatársaival együtt. Tulajdonképpen ezek a tanulmányok juttatták sikerre a Ramsey-modellt, ami végül is megalapozta a modern dinamikus makroökonómia fő karakterisztikumát: az optimalizáló reprezentatív ügynököt (Oiko Nomost, Phelps Solowia királyságának eszes fickóját, aki a királyság legjobb megtakarítási rátájának helyes becslésével elnyerte a kitüzött díjat) végtelen időhorizonton. $E z$ az egyszerü keret tette lehetövé, hogy a közgazdászok mikroökonómiai alapokra helyezzék

${ }^{5}$ Ezt, a szerintünk is kissé furcsa megfogalmazást az tette szükségessé, hogy David Cass a vele készített interjúban (Spear - Wright 1998) tagadta, hogy akár neki, akár pedig a PhD témavezetőjének, Hirofumi Uzawának bármiféle tudomása lett volna Ramsey cikkéröl az 1965-ös tanulmánya megírása előtt. (Persze kérdés, hogy ez tekinthető-e erénynek?) Az interjúban foglaltak azonban semmilyen okot sem adnak arra vonatkozóan, hogy kételkedjünk az állításában. 
a makroökonómiát. Sokan úgy gondolják, ha Keynes megértette volna a Ramsey-modellt (amit saját maga ismert el, hogy nem), a makroökonómiai gondolkodása egészen más lett volna.

Időközben a matematika imázsa is megváltozott a szigor vonatkozásában. A finom distinkció a „szigor” mint dologi-redukciós kvantifikálás és a „szigor” mint formális kvalitatív deriválás között következett be, ami elvezetett az ökonometriához és a matematikai közgazdaságtanhoz, vagyis az alkalmazott közgazdaságtan és a közgazdasági elmélet megkülönböztetéséhez.

\section{Az ökonometria megszületése: Haavelmo forradalma}

A determinisztikus világnézet nyújtotta idilli képet egyszeriben beárnyékolta a relativitáselmélet és a kvantumelmélet megjelenése, ami valósággal sokkolta a természeti jelenségek magyarázatainak klasszikus mechanikai elméleteit, csakúgy, mint a differenciálegyenletek nyújtotta matematikai eszközök kizárólagos alkalmazását. A jelenségek klasszikus értelemben vett alapvető indeterminizmusa a molekuláris és a kozmikus rétegekről hosszas vitát kezdeményezett a tudományelméleti irodalomban a mechanikus világnézet relevanciájáról. ${ }^{6}$ Amikor a jelenségek lényegében indeterminisztikusak, nyilvánvalóan kétségbe vonható, hogy vajon a determinisztikus, aritmomorfikus természeti törvények (vö. Georgescu-Roegen 1971) megfogalmazásának egyáltalán van-e értelme. A valóság sztochasztikus leírásai az egyetlen értelmes közelítésnek tekinthetők a fizikai jelenségek magyarázatára. Ugyanakkor feltehető, hogy a determinisztikus természeti törvények a valóság jó közelítését képviselik az emberek által azonnal megfigyelhető skálán. Szigorúan matematikai szempontból ez vezetett ahhoz, hogy kettéváljanak az úgynevezett antiformalisták és a formalisták, akik közül az előbbiek a matematika fejlődését a kísérletekhez kapcsolták, míg az utóbbiak a szigor kivételével a minden korláttól mentes fejlődést preferálták. Természetesen e folyamat hatással volt valamennyi olyan tudományterület fejlődésére, amelyik használta a matematikát, így a közgazdaságtanéra is.

$\mathrm{Az}$ ökonometriai elmélet és gyakorlat fontosságát egy nagyon egyszerü okból emelhetjük ki: hasonlóan az összes többi társadalomtudományhoz, a közgazdaságtan is komoly hátrány mellett dolgozik - egy felettébb korlátozott képesség mellett, hogy irányított kísérleteket végezzen. ${ }^{7}$ A (többnyire) nem kísérletezö tudományunk az ökonometriát használja fel a vegyész laboratóriumát helyettesíteni. E technikák nélkül kevés reményünk lenne a megfigyelésből egy szisztematikus tudás származtatására; a „morálfilozófia” egyik ága lehetnénk még mindig, mint Adam Smith idejében. De a statisztikai következtetés e hatékony eszközeivel a közgazdászok ténylegesen megismerhetik az összefüggéseket jóllehet csak statisztikai értelemben. Biztosak lehetünk abban, hogy tudományunk egy valószínűségi tudomány - állítja Blinder; , „egy közgazdász számára minden szám egy becsült érték standard hibával". Ezek a gondolatok Haavelmo (1944) érvelését tükrözik, ami elindí-

\footnotetext{
${ }^{6}$ A hullámfüggvények közgazdasági adaptálása is megfordult néhány ambiciózus kutató fejében, de ezek a kísérletezések kevésbé voltak meggyőzők és visszhang nélkül maradtak.

7 Neumann János határozottan megvédte a közgazdaságtant azokkal a vádakkal szemben, hogy nem jó tudomány, mert nem lehet kísérletezni benne, és mert (az 1950-es évek elején!) a statisztikai mintái túl kicsinyek. Azzal érvelt, hogy a modern geometria és matematika alapja, azaz a csillagászat tipikusan olyan tudomány, amelyben nem lehet kísérletezni, és amelyben alig fél tucat statisztikai állapot (a Nap, a Föld, a Hold és néhány ismert bolygó) volt elérhető.
} 
totta a gyakorlati ökonometria szédületes fejlődését: a valószínűségi elmélet alkalmazása átíveli az „elmélet és mérés” közötti szakadékot, mégpedig azáltal, hogy képes magyarázatot adni a tényleges statisztikai adatok és az elméleti értékek közötti eltérésekre.

$\mathrm{Ez}$ nem volt igaz egy évszázaddal ezelőtt. Az akkori közgazdaságtan többé-kevésbé tisztán deduktív logikára és történeti leírásra volt korlátozva. Biztosak lehetünk abban, hogy a deduktív logika bármely tudománynak alapköve. De hogy túlhaladjuk azt, ahol 1900-ban voltunk, tudományunk megkövetelte elöször is azt a nagyon fontos éleselméjűséget, hogy a közgazdasági modellek állításokként posztulálják a valószínűségi eloszlásokat, és másodszor, az olyan technikák halmazát, mint például a többszörös regresszió, amelyek statisztikailag akarták szabályozni mindazt, ami a kísérletek alapján nem volt szabályozható. Ahhoz, hogy kiválasszuk az okot és okozatot, olyan gyakorlati megoldásokra volt szükségünk, amelyekre az ökonometriában mint identifikációs problémákra hivatkozunk. Kétségkívül ezek a pótszerek rosszabbak a valós dolgoknál. Egy természettudósnak, aki gondosan szabályozott kísérleteket végezhet laboratóriumában, jóval kevesebb különleges (és tökéletlen) statisztikai módszerre van szüksége, amelyek közül sok egybefon valamilyen elméletet a statisztikai következménnyel. De a modern ökonometria hatalmas javulás ahhoz képest, ami előtte volt.

1929-ben Frisch publikált egy tanulmányt a Nordic Statistical Journalban Correlation and Scatter in Statistical Variables címmel, és annak egy kibővített változatát 1934-ben Statistical Confluence Analysis by Means of Complete Regression Systems címmel - ezekben elöre tekintett és néhány olyan problémával foglalkozott, amelyek a regresszió és a korreláció elemzésében merülnek fel, ahol is multikollinearitás létezik, azaz ahol a tanulmányozott egyenlet mellett vannak a kérdéses változóhoz kapcsolódó más egyenletek is. Ezt követően, 1943 januárjában az Econometricában jelent meg Frisch tanítványának, Trygve Haavelmonak ${ }^{8}$ úttörő tanulmánya The Statistical Implications of a System of Simultaneous Equations címmel. Bár a tanulmány szüken csak 12 oldalnyi terjedelmü, de ez is jelzi a Cowles Bizottság néhány legfontosabb egymást követő kutatásainak kezdetét. Egyébként, Haavelmo a nemzeti jövedelem háromegyenletes elméletét tekintette, és vizsgálta az egyik egyenlet megfigyelt idősoradatokhoz történő illesztésének konzekvenciáit a regressziós analízis hagyományos legkisebb négyzetek módszere (OLS) segítségével.

Az egyenes megfigyelt ponthalmazhoz történő illesztésének statisztikai problémája az egyenes egyenletében szereplö ismeretlen konstansok (paraméterek, ahogyan a közgazdászok nevezik) numerikus értékeinek becslése. Például Haavelmo fogyasztási egyenletében a paraméterek, amelyeket becsülni kell, az a és $\mathbf{b}$, és az egyenlet: a nemzeti fogyasztási kiadás bármelyik évben egyenlő az az évi nemzeti jövedelem a-szorosa plusz b , plusz egy véletlen zavar (random disturbance), a „fehér zaj”, ahogyan ő nevezi. A véletlen komponensek miatt lehetetlen megtalálni a paraméterek pontos értékeit. Az ismeretlen paraméterek becslésének egy nagy hatékonyságú általános módszere, amelyet maximum-likelihood módszernek neveznek, azonban már rendelkezésre állt; $R$. A. Fisher (1912) gondolta ki közvetlenül az utolsó előtti századforduló után.

\footnotetext{
${ }^{8}$ Haavelmo Frisch tanítványa és szerzőtársa volt az Oslo Egyetem Közgazdaság-tudományi Intézetében, és több amerikai egyetemen is dolgozott különböző alapítványok ösztöndíjaival. 1942-től 1943 végéig a norvég kormány képviseletén dolgozott New Yorkban és Washingtonban, és rendszeres résztvevője volt Marschakkal, Walddal és másokkal együtt a New Yorkban tartott híres hétvégi ökonometriai szemináriumoknak. Marschak felkérésére lett a Cowles Bizottság kutató munkatársa 1943 júliusában,, és Norvégiába történő visszatéréséig, 1947 márciusáig ott dolgozott.
} 
Érdekes itt hivatkozni Jevons 1874-ben publikált The Principles of Science címü mesterművére, amelyben a tudományos következtetési elméletéről számolt be. Az indukció szerinte egyszerüen a dedukció inverz alkalmazása. Míg síkra száll a hipotetikus deduktív módszer alkalmazásáért, Jevons amellett érvel, hogy a premisszákban fel kell sorolni az összes olyan lehetséges esetet vagy példát, amelyekből az empirikus következtetés levonható. De a legtöbb dologra egy ilyen teljes felsorolás nem lehetséges a gyakorlatban. Következésképpen az „általános törvények” legfeljebb csak „valószínűek”. A folyamatba bevezetett egy episztemológiai valószinüségi elméletet, és úgy érvelt, hogy a valószinüségek egyszerüen a "tudatlanság mértékei”, vagy - ahogy nevezni szerette azokat - a "racionális várakozás" mércéi. Jevons az „indukciós inverz-valószínűségi elméletében” lényegében a maximumlikelihood módszer filozófiáját fogalmazta meg, nevezetesen, hogy egy esemény „legvalószínűbb" okát úgy származtathatjuk, hogy ha megvizsgáljuk az összes lehetséges hipotézist, levonjuk belölük az összes lehetséges következtetést, összehasonlítjuk öket a tényekkel, és végül kiválasztjuk azt a hipotézist, amelyik a legnagyobb valószínüséggel eredményezi azt az eseményt. „Ha egy eseményt egy bizonyos számú olyan különböző okok bármelyike okozhat, amelyek mind a priori egyformán valószínűek, azon okok egzisztenciájának valószínüségei, amelyekből következtetünk az eseményre, arányosak az ezen okokból származtatott események valószínűségeivel." (Jevons 1874:242-243.) Jevons módszere egyszerüen Bayes tételének újrafogalmazása. Egészen pontosan: Thomas Bayes, 18. századi angol matematikus azt javasolta, hogy amikor nem tudjuk, mit hoz a jövő, akkor állapítsuk meg az összes lehetőség előállásának valószínűségét, és ezeket az esélyeket használjuk fel döntéseinkben az okok és az okozatok felcserélhetőségét elfogadva. Például tegyük fel, hogy $P(x \mid A)=p, P(x \mid B)=q$ és $P(C \mid x)=r$ rendre az $A, B$ és $C$ hipotetikus okokból származó $x$ következmény feltételes valószínűségei. Így a hipotéziseket a következő számításokkal értékelhetjük: $P(A \mid x)=p /(p+q+r), \quad P(B \mid x)=q /(p+q+r)$ és $\quad P(C \mid x)=r /(p+q+r)$, és kiválasztjuk közülük a legnagyobb valószínüségüt. Az elv eléggé egyértelmü. Azonban az a következtetése, hogy az induktív tudás csak valószínü - csakúgy, mint David Hume filozófiai eszmevilágában -, szembeszállt az akkori idők tudományos közvéleményével, és nem kis bonyodalmat okozott.

Haavelmo is visszatér ehhez a gondolathoz az 1944-es Econometricában megjelent cikkében, amely szerint a modellek paramétereinek becslésére használt statisztikai módszerek jóval nagyobb lehetőséget nyújtanak az elmélet és a valóság közötti szakadék áthidalására. Ezzel a megközelítéssel sokkal inkább az áll összhangban, hogy az eddigi determinisztikusnak vélt gazdasági törvények helyett a kutatások abból indulnak ki, hogy maga a vizsgálandó kapcsolat is valószínűségi alapon áll, és az empirikus megfigyelések, azaz a statisztikai adatok is a valószínűségi változókból vett mintát mutatják. Ez viszont azt jelenti, hogy az adatokban tapasztalt hiba nemcsak a mérés pontatlanságának tulajdonítható, hanem annak is, hogy az a jelenség, amit mérni akarunk, szintén valószínűségi alapon jelenik meg. A valószínűségi elmélet ily módon történő alkalmazása átíveli az „elmélet és mérés” (theory and measurement) közötti szakadékot, mégpedig azáltal, hogy magyarázatot ad a megfigyelt adatok és az elméleti értékek közötti eltérésekre. Haavelmo érvelése mérföldkőnek számított az alkalmazott közgazdaságtan (ökonometria) fejlődésében: a becslések és a statisztikai következtetések lehetővé tették a régóta hiányolt természettudományos kísérletezéshez hasonló szimulációk bevezetését a közgazdaság-tudományba is. Ugyanakkor az is világossá vált, hogy a gazdaság müködése nem mindig magyarázható pusztán logikai úton az általános egyensúly determinisztikus rendszerében, ami elvezetett annak elismeré- 
séhez is, hogy empirikus megfigyelésekkel is igazolni lehet hipotéziseket, vagyis a közgazdasági kutatások is alkalmasak a megfigyelt jelenségek magyarázatára és elörejelzésére. 70 évnek kellett eltelnie, míg Haavelmo el tudta fogadtatni Jevons eszméjét a közgazdaságtudományban, ami szintén jelentős eseménynek tekinthető a közgazdaságtan tudománnyá válásában.

\section{Matematikai formalizmus a közgazdaságtanban}

„Az világos, hogy a közgazdaságtannak, ha az egyáltalán tudomány, matematikai tudománynak kell lennie." (Jevons, 1871:3.)

Alighogy sikerült kikászálódni Wittgeinstein Tractatusának segítségével a matematika logikai kudarcából, újabb veszélyforrásként már ott leselkedett az előszobában Hilbert matematikai formalizmusa, amely a matematika egészének teljes és konzisztens axiomatizálását tüzte ki célul. (A konzisztens szó itt most azt jelenti, hogy ellentmondások nem származhatnak magából a rendszerből.) A formalizmust természetesen nem kerülhette el a közgazdaságtan sem. Weintraub (2002) szerint a közgazdaságtan formalizmusa feletti modern viták a matematika történetéről, a közgazdaságtan történetéről, a matematika és a közgazdaságtan közötti viszony történetéről szóló félreértéseken alapulnak. Még speciálisabban: széles körben elterjedt konfúzió uralkodik a „szigor”, az „axiómák”, a „formalizmus” és a „matematika” természetéről és a közöttük lévő összefüggésekről. Egyáltalán, amikor egy közgazdász a matematika és a közgazdaságtan kapcsolatáról beszél, mit ért matematikán? Matematikai tételeket, propozíciókat és definíciókat? Vagy ekvivalenciát a formális, az absztrakt, az axiomatizált és a matematikai jelzők között?

Az elmélettörténészek számos bizonyítékát adják annak, hogy mára az absztrakt közgazdaságtannak kifejlődött egy olyan ága, amelynek semmilyen kapcsolata sincs a konkrét tényekkel, és csaknem elválaszthatatlanok a tiszta matematikától. Hosszasan idéznek az olyan köztiszteletre méltó közgazdászoktól, mint Ragnar Frisch, Henry Phelps Brown, Wassily Leontief, Káldor Miklós és Harry Johnson, akik az absztrakt és a matematikailag mesterkélt érvelésekben a közgazdasági értekezések elszegényesítését látták. Mások viszont úgy vélekednek, hogy a közgazdaságtan fejlődött a matematika nélkül is, de gyorsabban fejlődött vele, és átláthatóvá tett több száz közgazdasági indoklást is. A közgazdaságtan elméletei, a termelési függvények metaforái, a gazdasági növekedés és verseny logikája stb. mind-mind látványosan zavarossá válnának a matematika használata nélkül.

\section{David Hilbert formalizmusa}

David Hilbert (1862-1943) 1885-ben doktorált Lindemann vezetésével a Königsberg Egyetemen. Tézisének címe: Über invariente Eigenschaften specieller binärer Formen, insbesondere der Kugelfunctionen. 1886-tól 1893-ig tanított a Königsberg Egyetemen, majd a Göttingen Egyetemen nyugállományba vonulásáig, 1930-ig. Hilbert kutatási eredményei a legnagyobb befolyást gyakorolták a geometriára Eukleidész után. Az eukleidészi geometria axiómáinak szisztematikus tanulmányozása tette lehetővé, hogy 21 axiómát megfogalmazzon, és elemezze azok jelentőségét. Az 1899-ben közzé tett Grundlagen der Geometrie címü könyvében formális axiomatikus alapokra helyezte a geometriát. Könyve számos 
új kiadásban is megjelent, és óriási szerepet játszott a matematika axiomatikus közelítésének előmozdításában, ami a diszciplína fő karakterisztikuma volt az egész 20. században. Hilbert a matematika számos területéhez, többek között az invarianciák, az algebrai számmezők, funkcionálanalízis, integrálegyenletek, matematikai fizika és a variációszámítás fejlesztéséhez járult hozzá, de a legmaradandóbbat a különböző területek szintézisében, a matematika egységesítésében alkotta.

A 20. század elején az intuicionizmus, a logicizmus és a formalizmus voltak azok a vezető iskolák, amelyek készek voltak megoldani a matematikai alapokban jelentkező problémákat. A matematikusok, a logikusok és a filozófus matematikusok Hilbertet tekintették azon új áramlat vezérének, amit formalista programnak neveztek. A standard kronológia, amely elöállítja a formalizmust és az intuicionizmust mint különálló kereteket a matematika alapjainak vizsgálatára, Fregével, Cantorral és Peanóval kezdődik, és ezután jut el Russelhez és Whiteheadhez. A következő - és Lakatos (1976) szerint remélhetőleg az utolsó - nagy próbálkozás a matematika eukleidészi jellegének kimutatására David Hilbert formalista programja volt. A formalista program lényegében egy „kiáltvány” volt a matematikusok felé, hogy bebizonyítsák a matematika konzisztenciáját a matematika korlátain belül. „Ha a logicista program kudarcát az ellentmondások okozták, akkor legföbb feladatunk abban áll, hogy a matematika makulátlan testét megtisztítsuk az ellentmondásoktól" - vallotta Hilbert. A formalista filozófia szintaktikai kalkulusokkal azonosítja a matematikai elméleteket, melyekkel szemben két fö követelményt támasztott: (1) a kalkulus ellentmondásmentes legyen (ez a követelmény tulajdonképpen helyettesíti az igazság követelményét, és ebben az értelemben a Hilbert-program nem egyértelmüen eukleidészi, annyiban viszont igen, hogy a matematikát tisztán bizonyító tudománynak tekinti); (2) a kalkulus legyen teljes, vagyis minden megfogalmazható tételt bizonyítani vagy cáfolni tudjunk benne, és le tudjunk benne vezetni minden olyan állítást, amelyet kevésbé szigorú megfontolások alapján korábban igaznak ítéltünk.

A fenti kronológiával szemben Hilbert axiomatizációval kapcsolatos vizsgálatait mások világosan és határozottan a fizikai axiomatizációval azonosítják és nem a halmazelmélet ellentmondásaival. Ezzel nem azt akarják mondani, hogy Hilbert nem vizsgálta az aritmetika alapjaiban megjelenő problémákat. Hiszen a Grundlagen második kiadása külön fejezetet szentelt a geometria lehetséges ellentmondásainak. Hilbert a geometria konzisztenciájának kérdését az aritmetika konzisztenciájára redukálta le, mivel bármely eukleidészi geometriában létező ellentmondás megjelenik a valós számok aritmetikai rendszerében is. Így az 1900-as 23 probléma felsorolásában a második jelöli meg az aritmetikai axiómák kompatibilitásának bizonyítását.

Bár nemcsak a Hilbert-féle második probléma az, ami kérdéses. Vele egy időben jelent meg a hatodik problémája, a fizika axiomatizálása is. Így egy olyan kronológia, amely a történeti kontextust halmazelméletiként fejti ki, kihagyva a fizikát, potenciálisan komoly félreértést eredményezhet. Nem szabad elfelejteni ugyanis, hogy Hilbert a göttingeni matematikai intézet professzora volt, és előadásai a matematikai fizikáról szorosan kapcsolódtak a fizikában felmerülő problémákhoz a 20. század fordulóján, aminek következtében az axiomatizálás témakörében végzett kutatásait, előadásait megtöltötte fizikai vonatkozású eredményekkel. Hilbert valamikor 1894-ben ismerkedett meg Hertz eszméivel, amelyek jelentős katalizátorként hatottak a geometria axiomatizálása irányába Hilbert kutatásaiban. Ekkor már Hilbert előadásai tartalmazták azokat a gondolatokat is, hogy a geometria olyan tudomány, amelynek esszenciái oly mértékben fejlettek, hogy minden állítása már 
logikailag következtethető a korábbiakból. Éppen ez az axiomatizálási folyamat az, ami transzformálja a geometria természettudományát a maga tényszerü, empirikus tartalmával egy tiszta matematikai tudományba. Ez azt az üzenetet is magában hordozza, hogy nincs semmilyen nyilvánvaló ok arra vonatkozóan, hogy egy hasonló axiomatizálási folyamat nem következhet be bármely más természeti tudományágban. Weintraub (2002) kutatásaiból tudjuk: Hilbert előadásainak kéziratában olvasható, hogy az összes más tudomány, de mindenekelött a mechanika, az optika, az elektromosság elmélete stb. a geometriában lefektetett modellek szerint kezelendők.

Az angol matematika 1900 körül még mindig egyféle keveréke volt a geometriának és az alkalmazott mechanikának, együtt a matematikai igazság inkonzisztens tükröződéseivel mind a logikában, mind a természetben. Ugyanakkor a kontinentális európai országokban új irányzatok jelentek meg a bizonyításról, a „szigor” új eszméiről, amelyek mind a matematika alapjai, nevezetesen a halmazelmélet, az aritmetika és a logika közötti összefüggésekre helyezték a hangsúlyt. Ezért nem tekinthetö tudományos forradalomnak az, amit David Hilbert hirdetett meg Zürichben az 1927-ben megtartott Axiomatisches Denken címü előadásában. Az csupán csak egy világos és jól előadott matematikai értekezés volt Hilbert tudományos perspektívájáról. Ebben az időben már egyre több matematikus, beleértve az angolokat is, kutatott egységesítő fogalmakért, és megkísérelték a minimumra csökkenteni a primitív terminológiák és axiómák számát. Mindezt a halmazelmélet paradoxonjai motiválták. Az axiomatikus gondolkodásban és a formalizmusban az axiómák függetlensége és konzisztenciája a meghatározó. Az előbbi azt jelenti, hogy egyik axióma sem deriválható más axiómá(k)ból. Egy axiómahalmaz konzisztenciája pedig azt jelenti, hogy nem jelenik meg ellentmondás az elméletben az axiómák vagy egy halmaznyi fundamentális propozíció igazságának feltevésével. Bár bizonyos esetekben éppen ezek az ellentmondások segítik a tudomány fejlődését. Hilbert az ellentmondás evolúciós hatására hozza fel példaként, hogy a kvantumelmélet és az atom belső szerkezetéröl szerzett egyre bővülő tudásunk vezettek el azokhoz az új törvényekhez, amelyek világosan ellentmondanak a korábbi elektrodinamikai elméleteknek, amelyek lényegében a Maxwell-egyenletekre épültek. E megállapítása alapján sürgette előadásában a modern elektrodinamika létrehozását, ami új megalapozást és a meglévő jelentős átalakítását igényelte.

Ugyanakkor Hilbert a matematika imázsának rekonstrukciójára hívta fel a matematikusok figyelmét, és erőteljesen kiemelte, hogy a formalizáció és az axiomatizálás, az általa adott értelmezésben, a kulcs az új tudományos munkához. Új kutatási programot hirdetett meg, mégpedig a matematikai vagy alkalmazott matematikai és fizikai, vagy éppenséggel a társadalmi elméletek axiomatizálásának a programját.

Tehát a matematika formalizálása egyértelműen David Hilbert nevéhez füződik, de sok közgazdasági elmélettörténész a közgazdasági formalizmust is hozzá vezeti vissza. Például Lionello Punzónak a Hilbert-féle axiomatizálásról adott értelmezése és a matematikai formalizmusról írt narratívája (Punzo 1992) Hilberttől Neumannon keresztül a bécsi Menger-körig és így Wald Ábrahámig, és innen a versenyzői egyensúlyi modelleknek Debreu és a Hilbert-befolyásolt matematikai tanárokig, köztük a bourbakistákig, széles körü áttekintést ad. A formalizmus az 1930-as években, Bécsben a Wald és Neumann által megfogalmazott kompetitív egyensúly egzisztenciájának bizonyításán keresztül vonult be a közgazdaságtanba. Vagyis az általános egyensúlyelméletet, így a neoklasszikus közgazdaságtant is a hilberti formalizmus alakította, de már ott bábáskodott a bécsi születésénél is. Hilbert fiatal munkatársa, Neumann János volt az, aki előre tolta az új eszmék szekerét, 
amikor is a régi determinisztikus mechanikai nézöpontot kicserélték a matematikai analógia eszméjén alapulóval. A régi redukcionizmust felváltották az újjal, amelynek kulcseszméje már a matematika-központúság volt, amelyen egy tisztán logikai-deduktív sémát értettek. Neumann szemlélete alakította az általános egyensúlyelméletet és a játékelméletet, ami újjászerkesztette a közgazdasági elméletet is. Sokan ezért tekintik David Hilbertet az új közgazdaságtan szellemi nagyapjának.

\section{Az új redukcionizmus}

A 20. század második dekádjának végére Hilbert és mások olyan matematikai struktúrákat fejlesztettek ki, amelyek hasznosnak bizonyultak az alkalmazott területek modellezésében. (Hilbert az elektrodinamikát, a fénytant, a termodinamikát, a kvantumelméletet stb. említi.) A kései 19. századi redukcionizmus helyettesítése, vagyis a jelenségek mechanikai struktúráinak matematikai modellekkel történö kicserélése, új kutatási programként a matematikai redukcionizmust eredményezte, ami fundamentális szempontokat tükrözött magának a matematikának a megalapozásában is. Speciális figyelmet követelt meg mind a halmazelmélet, mind az aritmetika axiomatizálásában, mivel azok konzisztenciája biztosította más, azokon alapuló rendszerek konzisztenciáját is. Például a valós számok felépíthetők az egész számok vételével, hozzáadva a Dedekind-féle axiómát. Ha az aritmetika konzisztens, akkor a valós számok halmazának is annak kell lennie, szólt az állítás. Amennyiben konzisztens rendszerünk van, akkor kifejezhetö benne egy propozíció, ami vagy igaz, vagy hamis lesz abban a rendszerben, különben a rendszer nem teljes. Természetesen mindig hozzáadhatjuk a rendszerhez, újabb axiómaként, azt a propozíciót, amelyik sem nem igaz, sem nem hamis az adott rendszerben, így téve teljesebbé azt. Következésképpen egy rendszer teljessége a propozíciók eldöntéséhez van kötve, vagyis magához a matematikai bizonyítás lehetőségéhez. Ebből is világos, hogy a halmazelmélet és az aritmetika mind a konzisztencia, mind a teljesség szempontjából kutatási programként jelent meg a matematikában. Ha meg lehetett állapítani, hogy az aritmetika és/vagy a halmazelmélet, vagy még pontosabban, az aritmetika és a halmazelmélet különös axiómái mind konzisztensek, mind teljesek, akkor a matematika megoldotta a bizonyosság gnoszeológiai kutatását. Hilbert megemlíti, hogy az axiomatizálás cégtábláján a tudomány vezető szerepére a matematika van feltüntetve.

Hilbert matematikával szembeni adóssága két részből állott: az egyik változást sürgetett a matematikai tudásban, a másik pedig a matematika imázsának javítására hívta fel a figyelmet. Weintraub az elsőt Finistic Program for the Foundations of Arithmeticnek, röviden FPFA-nak, a másikat pedig Axiomatic Approach-nek, illetve AA-nak nevezte. Weintraub értelmezésében csak az AA játszott szerepet a matematikai közgazdaságtan fejlődésében. Az FPFA-t a matematikai filozófia történészei „Hilbert formalista programjának" nevezték. Ez az, aminek a relevanciáját megkérdőjelezte Kurt Gödel híres lehetetlenségi bizonyítása, ami megváltoztatta a formalizmus eszméit a matematikában, és jelentős hatással volt a közgazdaságtanban használt formalizált érvekre is. Véleményünk szerint Gödel tétele csak Lakatos Imre prezentációjában teszi teljessé Weintraub érvelését, és a következő pontban ezt elemezzük. 


\section{Kurt Gödel Lakatos-féle közelítésben}

A Hilbert-féle formalista program kudarcára - Lakatos szerint is - 1931-ben derült fény, amikor is Kurt Gödel két híres nemteljességi tétele bebizonyította, hogy a formalista filozófiának mindkét alapkövetelménye tarthatatlan: egyetlen, a matematika céljaira elég erős kalkulus sem lehet szintaktikai értelemben teljes, és egyetlen ilyen kalkulus sem képes bizonyítani magáról az ellentmondás-mentességet (vagyis nincs olyan matematikai elmélet, amelynek ellentmondás-mentességét önmagában bizonyitani tudnánk, és így a többi elmélet ellentmondás-mentességét erre visszavezethetnénk). Lakatos elismeri, hogy a matematikusközösség jelentős hányada még nem hajtott fejet e kudarc előtt, és a Gödeltételek negatív eredményeit a metalogikában, a bizonyításelméletben és hasonló területeken próbálja megkerülni, de szerinte az is belátható, hogy minden ilyen kísérlet, még ha bizonyos értelemben sikeresnek is tünik (mint például az aritmetika ellentmondás-mentességének a transzfinit indukcióra alapozott Gentzen-féle bizonyítása), menthetetlenül kilép az eredeti formalista program eukleidészi keretei közül: az ellentmondás-mentességgel és a teljességgel kapcsolatos intuíciónk alkalmatlan arra, hogy megalapozza a matematikát.

Tehát nem marad más hátra, mint hogy a további, kevésbé fontos történeti próbálkozások vizsgálata helyett immár levonjuk azt a drámai konklúziót, hogy a matematika nem lehet eukleidészi jellegü. Vagyis a matematika tudománya egyrészt nem tévedhetetlen: nem tudunk olyan mechanizmust mutatni, amely felelős lehetne a tévedhetetlenségéért. Másrészt, nem szigorúan bizonyító, ugyanis ehhez szükség lenne arra, hogy az axiómák a levezetett tételekhez képest feltétlen autoritással rendelkezzenek, ám a helyzet az, hogy sok esetben az axiómákat módosítjuk azzal a céllal, hogy a tételek igazságát biztosítani tudjuk (a viszony tehát megfordul - lásd cáfolás). Végül pedig a matematika nem is tisztán formális, hiszen a tisztán formális rendszerek nemcsak arra alkalmatlanok, hogy szóljanak valamiről, hanem arra is, hogy megfeleljenek a velük szemben támasztott, intuitív formai elvárásainknak.

Azok az elképzelések tehát, amelyek arra törekedtek, hogy megállapítsák, milyennek is kell lennie a matematikának, vagyis hogy előírják a matematika számára, hogyan is kell ideális esetben működnie, tarthatatlannak bizonyultak. A matematika filozófiájának inkább abból kell kiindulnia, hogy leírja a matematika valódi müködését. E célból pedig a matematika történetéhez kell fordulnia: meg kell vizsgálnia, hogy valójában mi is az a módszer, amelyet a sikeres, a tudás gyarapodását szolgáló matematikai tevékenység követ. Részben ezt fejezi ki az a híres lakatosi tézis (Immanuel Kant egy filozófiai tételének parafrázisa), amellyel az egyik leghíresebb tudományfilozófiai tanulmányát kezdi: „A tudományfilozófia a tudománytörténet nélkül üres, a tudománytörténet a tudományfilozófia nélkül vak." (Lakatos 1976/1981:65)

A tézis első részét tehát az eddigiek alapján könnyen magyarázhatjuk: minden olyan tudományfilozófia, vagyis a közgazdászok terminológiájában metodológia, ami nem veszi figyelembe az általa vizsgált tudomány történetét, elvéti a saját tárgyát, hiszen nem ismeri meg annak valódi müködését, természetét. (A tudományelméletek módszertanának e fontos követelményét fogalmazta meg Lakatossal egy időben Thomas S. Kuhn, és kettejük hatására ma már kevés olyan tudományfilozófus van, aki ennek igazságát kétségbe vonná.) A tézis második fele azonban ennél jóval problematikusabb: azt állítja, hogy minden olyan történeti kutatás, amelyik nem egy filozófiai koncepció mentén halad, meddő és értelmetlen. Hiszen a történész nem tiszta végcélként, minden további céltól mentesen fordul a tudomány törté- 
netéhez, hanem azzal a céllal, hogy választ kapjon a kérdésre, hogy mi a tudomány. (És ezzel szoros összefüggésben: mi a racionalitás?) Ez a filozófiai kérdés irányít minden történeti kutatást, az erre adott előzetes válaszunkat próbáljuk alátámasztani minden olyan történeti adattal, amelyet ezen elöítéletünk szerint választottunk ki. „A történeti adatok halmaza ugyanis tökéletesen rendezetlen és áttekinthetetlenül terjedelmes, és elengedhetetlen, hogy rendelkezzünk olyan filozófiai elvárásokkal, melyek mentén a kusza adatokat egy történeti szállá rendezzük": ezt nevezi Lakatos (1976/1981:67) racionális rekonstrukciónak.

Ez a fogalom aztán óriási vitákat keltett, és mind a mai napig heves tiltakozást váltott ki a tudománytörténészek többségének részéről. Mivel a kérdés részletes tárgyalása Lakatos általános tudománytörténeti írásainak vizsgálatát tenné szükségessé, és egy ilyen vizsgálat meghaladja e cikk kereteit, szorítkozzunk most csak a híres lakatosi tézis első részére, vagyis arra a követelményre, hogy minden tudományfilozófiai elméletnek a tudománytörténet alapos ismeretéböl kell kiindulnia.

Mit látunk akkor, amikor a matematika történetére tekintünk? A formalista matematikai filozófiával szembeni vita után rögtön szembetűnő az a fontos tanulság, hogy a matematikai elméletek sohasem formálisként adottak a matematikusok számára. A formális elméleteket a matematikusok hozzák létre, méghozzá azzal a céllal, hogy precíz, fogalmilag rögzített keretbe foglaljunk egy informális elméletet. Mármost ez az informális elmélet az, ami elsőbbrendű a formális rendszerhez képest - ám ennek természetét igen nehéz megragadni, hiszen amíg nem kristályosodik ki a formális rendszer keretei között, addig ellenáll az egzakt fogalmi vizsgálatnak. A matematikai elméletek igazságának forrására vonatkozó kérdés tehát visszavezethető eme informális fogalmi rendszerek igazságának kérdésére, ám erre a kérdésre Lakatos nem ad hagyományos, egyetlen mechanizmust kitüntető választ. Tapasztalatból kiinduló elvonatkoztatás, a platóni örök igazságok birodalmának intellektuális szemlélete, a matematikai objektumok fogalmi konstrukciójából adódó intuíció Lakatos szerint mindezek szerepet játszanak az informális fogalomrendszer kialakításában. A matematikai filozófiát azonban nem ez az ismeretelméleti probléma érdekli, hanem az, hogy miként jön létre a fogalmak rögzített rendszere, vagyis az a folyamat, amelyik a matematikai sejtéstől a matematikai tudásig vezet. (Kitűnő olvasmány erre Simon Singh (1977) magyarul is megjelent könyve a matematika szent Grálja, a híres Fermat sejtés igazolásának történetéről.)

A bizonyítások és cáfolatok együttese egy olyan történeti folyamat racionális rekonstrukciója, amely Lakatos szerint kitünően alkalmas arra, hogy segítségével behatóan tanulmányozzuk, hogyan megy végbe a matematikai tudás gyarapodása. A Lakatos által vizsgált történeti folyamat a poliéderek elméletének 18-20. századi fejlődése, amivel figyelemmel kísérhetjük egy nem formalizált intuíció fokozatos fogalmi letisztulását és végül formális elméletté merevülését. A folyamat föbb lépései a következők:

1. Naiv sejtés. A matematikai kutatás mindig egy problémával kezdődik (és megjegyzendő, hogy mindig egy problémával is végződik). A probléma egy összefüggés felismerése, amely megfogalmazható ugyan, de nem ágyazható be olyan elméleti kontextusba, amelyben legitim és bevett módszerekkel bizonyíthatnánk. Ez tehát egyfajta felismerés, aminek forrása valamilyen intuíció, és semmiképpen sem egy deduktív matematikaképnek megfelelően kapjuk. Esetünkben ez a felismerés nem más, mint a (Descartes-)Euler-féle poliéder sejtés, vagyis az a meglátás (próbálgatások induktív igazolása alapján), hogy egy poliéderben a csúcsok száma plusz a lapok száma mínusz az élek száma egyenlő kettővel. 
2. Bizonyitások és cáfolatok módszere. A soron következő feladat az (ami egyben a matematika legfontosabb feladata), hogy létrehozzuk azt az elméletet, amelyben a fenti naiv sejtés tételként levezethető, vagyis rögzítsünk egy, a tárggyal kapcsolatos fogalmi keretet. Elöször is megpróbálunk egy naiv bizonyítást adni a tételünkre, más szóval: megmutatni, belátni, hogy a tétel igaz. Esetünkben ez a Cauchy-féle bizonyítást jelenti, vagyis amikor a poliédereket gumilapokként fogjuk fel, és képzeletben az élük mentén szétvágva és kiterítve őket, belátjuk a tétel igazságát. Ekkor azonban a matematikusközösség számos tagja szóvá fogja tenni a bizonyítás azon nyilvánvaló gyengeségét, hogy az a poliéderek mint gumilapok összessége egyszerüsítést használja ki, és könnyen hoznak olyan ellenpéldákat, melyekre a fenti tétel nem igaz - ez a fázis tehát a kritika fázisa. Az ellenpéldákat nagyjából két csoportra oszthatjuk: lokális és globális ellenpéldákra. A lokális ellenpéldát onnan ismerhetjük fel, hogy tulajdonképpen nem a tételünket cáfolja, hanem csupán egy kimondatlan lemmát, amelyet tudtuk nélkül kihasználtunk a bizonyításnál - ekkor a kérdéses lemmát kicserélhetjük egy olyannal, amelyik már kizárja az ellenpéldát. A globális ellenpélda valóban a tételünket cáfolja, ám ekkor sem vetjük el a tételt és annak bizonyítását, hanem módosítjuk a fogalmainkat, vagyis felülbíráljuk azt, hogy miről szól a tétel és a bizonyítás (például hogy mik azok a poliéderek). Ezáltal a bizonyítások, cáfolatok és bizonyításkritikák dialektikus kölcsönhatásán keresztül fokozatosan körvonalazódik egy fogalomrendszer, és ennek kapcsán egy kutatási program (a maga kemény magjával és heurisztikájával - lásd Lakatos tudományfilozófiai fogalomtárát), amely meghatározott keretet szab a matematikai tevékenység számára.

3. Deduktív elmélet. A kutatási program végül is létrehozza azt a (formális) elméletet, amelyben a kezdeti naiv fogalmaink és bizonyításaink immár pontos jelentést kapnak. (Esetünkben létrejött az algebrai topológia axiomatikus rendszere.) Ekkor a tevékenység redukálódik a tiszta rejtvényfejtésre (Kuhn fogalmát veszi kölcsön Lakatos), és érdekes elméleti problémák már nem merülnek föl. A formalista filozófia számára egyedül ez a fázis érdekes - Lakatos számára pedig ez a legkevésbé.

Itt meg kell említeni, hogy Lakatos szerint ugyanennek a fejlődési sémának a müködése érhető tetten a görög matematika kialakulásában is (volt tanárára, a híres matematikatörténészre, Szabó Árpádra hivatkozik ekkor), például a geometriában Thalész naiv sejtéseitől Eukleidész rendszerének létrejöttéig. És ami még érdekesebb, Lakatos ugyanezt a sémát látja érvényesnek a racionális mechanika születésére is: Kepler naiv sejtéseitől (amelyek fizikai bizonyítására akkor még semmiféle komoly elmélet nem állt rendelkezésére) egészen Newton axiomatikus megalapozásáig.

Mielőtt rátérünk Gödel szerepére, érdemes összefoglalnunk eddigi narratívánk föbb pontjait. Az előbbiekben láttuk, hogy számos közgazdász és elmélettörténész érvelt úgy, hogy a tradicionális közgazdaságtant lényegében felforgatták a 20. század első felében. Az új közgazdaságtan hibájaként rótták fel, hogy abban erőteljesen megnőtt a matematizálás és/vagy az axiomatizálás szerepe. A fordulatot mint „közgazdasági formalizmust” értelmezték, és egyértelműen a matematikai formalizmushoz kapcsolták. A matematika történészei és filozófusai a „formalista program” irányítójaként David Hilbertet jelölték meg. Lionello Punzo például úgy érvelt, hogy Hilbert eszméi jelentős hatással voltak a „marslakó” Neumann Jánosra, akinek eszméi alakították Morgenstern Menger-körének, Mengernek és Waldnak a nézeteit, és amelyek újra felszínre törtek USA-ban a Cowles Bizottságban és a The Theory of Games and Economic Behaviourben. A formalizmus vált a Cowles vezette Econometric Society missziójának metodológiájává és intellektuális forrásává, csakúgy, mint 
az Arrow-Debreu-féle általános egyensúlyelméletnek, ezzel biztonságossá és elfogadhatóvá téve a neoklasszikus közgazdaságtant.

Ezt az idilli képet valamelyest beárnyékolja, hogy Hilbert formalista programja kudarcot vallott Gödel bizonyítása következtében, és széles körben elterjedt az a hiedelem, hogy a formalista közgazdászokat megtévesztették, amikor az axiomatizálást gyümölcsöző metodológiának tekintették a tudományos vizsgálataikban. Ezt a nézetet erősíti az is, hogy a 20. század matematikai közgazdaságtanának kiváló elmélettörténészei is meglehetősen ambivalensek a matematika és a közgazdaságtan összefonódásáról. Például Mirowski úgy érvel, hogy a matematikai közgazdaságtan kibogozhatatlanul a fizikai redukcionizmushoz kötődött, és a piaci szereplő neoklasszikus elmélete nem más, mint a 19. századi energetika álruhában, és ezért képtelen magyarázó erővel rendelkezni. Weintraub azt állítja, hogy Gödel bizonyítása Hilbert Axiomatische Approach-át nem érintette, szemben Morris Kline matematikai történész véleményével, aki egyszerüen a „matematikába vetett bizonyosság elvesztésének" nevezte.

Gödel 1929-ben a doktori értekezésében az elsörendü predikatív kalkulus teljességével foglalkozott. Eredménye valamennyi interpretációjában meglepően pozitív állítást hozott Hilbert programját illetően. Egy évvel később azonban bejelentette, hogy talált egy olyan propozíciót, amelysenemigaz, senem hamisRusselésWhitehead PrincipiaMathematicájának formális rendszerében, csakúgy, mint Zermelo-Fraenkel axiomatizálásában. Ez a nagyszerü teljesítmény csaknem a félelem érzetét keltette a logikusokban és a matematikusokban. Gödel eredménye természetesen megrázta a tudományos világot, de még néhány évnek kellett eltelnie ahhoz, hogy megértsék az eredmények teljes hatását. Közben Gödel kiteljesítette az eredeti cikkében foglaltak hatását, és informális bizonyításokat adott olyan propozíciókra, mint a konzisztencia bizonyíthatatlansága az axiomatikus halmazelméletre, és az igazságfogalom formális meghatározhatatlansága.

Az 1930-as évek második felében Gödel eredményei már nem voltak kérdésesek. Megértették, hogy egyszer s mindenkorra szétfoszlatták Hilbert optimista FPFA- perspektíváját, vagyis hogy valamennyi tudományos ismeret végül is formalizálható és axiomatikusan fejleszthetö a matematika biztos alapjain. Érintetlenül hagyta azonban Hilbert Axiomatische Denken optimizmusát, azon felhívását, hogy axiomatikus megalapozásokból kutassanak alapokat és fejlesszenek elméleteket. Nem érintette Hilbert azon érvelését sem, hogy ahol csak lehetséges, formális szigort vezessenek be a tudományos munkákban. Gödel lehetetlenségi tétele nem befolyásolta a matematikusi tevékenység imázsát sem, hogy a matematikai ismeretet még biztonságosabbá tegye, és hogy az új tudományos ismeretet szervezett és szigorú módon kezeljék: nem némította el Hilbert felhívását az Axiomatische Denkenre.

Lakatos matematikai filozófiája Gödel lehetetlenségi tételének árnyékában azonban különös óvatosságra intette a matematikusokat és a matematikát felhasználó más tudományterületek képviselöit, így a matematikus közgazdászokat is. Intelmeinek esszenciáját maga Lakatos foglalja három pontba, amelyek a következők:

(i) a tudományokban a bizonyítás fogalmát korántsem használhatjuk olyan naiv módon, mint azt sokáig gondolták, és hogy a cáfolatoknak legalább akkora szerepe van, mint a bizonyításnak (Popper falszifikációelmélete);

(ii) a matematika nem azonos formális elméleteknek egy csoportjával, hanem elválaszthatatlan az emberi tevékenységtől, amellyel mi magunk hozzuk létre a matematikai vizsgálódás tárgyát (Pólya György heurisztikája); 
(iii) egy adott tárggyal kapcsolatos filozófiai gondolkodás nem merülhet ki a fogalmi rögzítettség megragadásában, hanem e helyett a fogalmi dinamikára kell fordítani a figyelmet, ugyanis csak így adhatunk számot ismereteink gyarapodásáról, a fejlödésről. A matematika filozófiájának tehát a matematikai bizonyosság elméletéből a matematikai fejlődés elméletévé kell előlépnie (Hegel dialektikája).

A matematikai formalizmus téveszméinek romboló hatását csak Kurt Gödel (1931) lehetetlenségi tételének sikerült megállítania, a tudományok „királynőjének” ismételten megtépázott tekintélyét pedig a magyar származású Lakatos Imre (1976) matematikai filozófiájának sikerült helyreállítania (további részletekért lásd Simonyi 1996).

Gödel 1930-as tanulmánya megmutatta, hogy az FPFA nem vezethetett sikerre, ugyanis lehetetlen volt bizonyítani, hogy az ismeretalapok konzisztensek lennének, és ne vezetnének ellentmondásra. A tétel mégis lehetővé tett egy alternatív közelítést, nevezetesen a "relatív bizonyosságot”, mivel gyakran kimutathatjuk a konzisztenciát a posztulátumok vagy axiómák megfelelően kibővített halmazában: ha egy $P$ propozíció eldönthetetlen volt az $A$ rendszerben, $P$-t hozzáadva $A$-hoz (vagyis így kibővítve az axiómarendszert), biztosítható $P$ igazsága. Másképpen: tetszőleges rendszerre az igazság konzisztenciaként teljesül abban a struktúrában, amelybe beágyaztuk.

Az igazság és a konzisztencia összefonódnak, és egy elmélet konzisztenciáját egy konzisztensnek ismert „modellhez” viszonyítva állapítjuk meg. Például Volterra, Evans, Edgeworth és Pareto a mechanikai redukcionizmust követte, hogy a tudományos érveléseiket szigorúvá tegyék. E szigor garantálta az igazságot, a közgazdasági modellnek egy fizikai modellbe történő beágyazásával vagy hozzácsatolásával. Ezzel szemben a matematikai igazság Hilbert AA-jában egy ettől különböző fogalmat követelt meg. A matematikának ez az új imázsa formálta át az új köntösben megjelenő matematikai közgazdaságtant. A szigor és az igazság összefüggése megőrzése végett a közgazdászok a szigort a közgazdasági tételek axiomatikus fejlesztésével társították. Az axiomatizálást ugyanis olyan módszernek látták, amely új tudományos felfedezésekhez vezethet: Hilbert kutatási programja ebben a formában talált magának utat a matematikai közgazdaságtanhoz, s nem kisebb személyiségen, mint Neumann Jánoson keresztül.

\section{Neumann János}

Neumann János (1904-1957) volt David Hilbert potenciális intellektuális örököse, annál is inkább, mert egész emberként vállalt részt Hilbert matematikával kapcsolatos munkájában. Ennek két bizonyítékát is megadhatjuk. Az első Neumann kutatása a logika és a halmazelmélet megalapozásában az 1920-as években, ami közvetlenül Hilbert FPFA-jához kapcsolódott, a másik a kvantummechanika axiomatizálásában kifejtett munkájának publikálása 1928-ban. Ez utóbbi manifesztálta Hilbert azon nézetét, hogy a tudományos elméletek hogyan formalizálandók abban az értelemben, hogy a fundamentális tételeik egy formális axiomatikus alapból fejlesztendők ki, abból, amit Weintraub Hilbert Axiomatic Approach-ának nevezett. 1930 végén már Neumann számára is világos volt, hogy Hilbert FPFA-ja, azaz Hilbert második programja elbukott. Annál is inkább, mert ő is jelen volt Königsbergben azon az 1930. szeptember 7-én tartott előadáson, ahol Gödel kifejtette a legújabb eredményeit. Söt 1930. november 20-án kelt, Gödelnek küldött levelében beszámolt arról, hogy felfedezett egy érdekes korolláriumot a tételéhez, nevezetesen a konzisztencia 
bizonyíthatatlanságát. Időközben azonban maga Gödel is bebizonyította ezt a második tételében és addigra már meg is jelentette.

1927-1928 körül kezdett Neumann János foglalkozni a kétszemélyes zérusösszegü játékok kérdésével, és egy szigorú bizonyítást adott a minimax tételre. Tanulmánya valamelyest kapcsolódik a termodinamika kérdéseihez, mivel a minimaximalizálandó célfüggvény hasonlít egy potenciálfüggvényre. Számunkra most ebben csak az az érdekes, hogy a játékok kezelését axiomatikusan fejlesztette ki, és így Neumann szemlélete ismét csak konzisztenciát mutat Hilbert artikulált közelítésével.

1936-ban publikálta a sokat ünnepelt növekedési modelljét, amely megalapozta 1) a modern egzisztenciabizonyításokat azáltalános egyensúlyi modellekben, 2) a lineáris programozást és az egyenlötlenségek duális rendszerét, 3) a turnpike-elméleteket, 4) a fixpontos elméleteket (bővebben lásd Zalai 1999). Ezzel a tanulmányával, ahogyan Samuelson fogalmazott: „Gyorsan átszökkelt a területünkön, és az már sohasem lesz ugyanaz” (Dore Chakravarty - Goodwin 1989:121). Goodwin retrospektív értékelésében a következőket írja a dolgozattal kapcsolatban: „A legnagyobb tévedést pályámon akkor követtem el, amikor odajött hozzám Schumpeter 1938-ban vagy 1939-ben és megkért, hogy készítsek recenziót egy nagyon fontos új publikációról - a Menger szemináriumon előadott és az Ergebnissében 1937-ben megjelent von Neumann-cikkről, azaz a Princeton Egyetemen, 1932-ben elhangzott előadás replikációjáról. Amikor megkaptam a cikket azonnal realizáltam, hogy belevette az összes megmaradó telepet és berendezést az éves kibocsátásba, amit elhamarkodottan teljesen irreálisnak ítéltem, és ítélem még mindig, bár visszatekintve látom a módszer mérhetetlen egyszerüsítő erejét. Mindenesetre - óh, jaj! - jeleztem Schumpeternek, hogy az nem több mint egy zseniális matematikai cikk, nem látva, hogy az Schumpeter szívéhez közel álló két szempontot is tartalmazott - egy rigorózus megoldást Walras központi problémájára, és annak bemutatását, hogy a profitráta a növekedésből és nem a tőke mennyiségéből származik. Amikor szerkeszteni kezdtem cikkeit a History utolsó fejezetpontjához, nem találtam hivatkozást rá, ami most úgy tünik nekem, hogy a XX. század nagy, kiemelkedő műveinek egyike, és kihagyása feltehetően az én vakságom eredménye volt. Zárt struktúrájának szép takarékos architektúrája mindenkit megfélemlít. Nyilvánvalóan előzmények nélkül, abból a termékeny agyból nőtt ki teljes virágzásában, megmutatva a gazdasági probléma megoldásának létezését, ahol az összes jószág a legalacsonyabb áron termelhető, és az ár egyenlő a költséggel és a kínálat az összes jószág keresletével, a maximális növekedés szükségességének megmutatásával együtt, amennyiben a dinamikus egyensúly létezik." (Dore - Chakravarty - Goodwin 1989:125.)

Axiomatikus fogalmi rendszerével kétségtelenül magán viseli a matematikai formalizmus nyomait. Az elsősorban matematikai modell sokszínü közgazdasági vonatkozásai eredményeként Ramsey modelljével vetekszik; bár a közgazdászoknak nem kellett olyan hosszasan várakozniuk, hogy megértsék Neumann üzenetét. Erről maga Káldor Miklós gondoskodott, aki mint a Review of Economic Studies folyóirat akkori föszerkesztöje felkérte Champernownet (1945-1946), hogy írja meg a modell közgazdasági értelmezését, amely ugyanabban a számban követte Neumann németröl angolra fordított cikkét, és amelyet később bizonyos szempontok alapján átértékelt Samuelson (1989).

A dinamika matematikai elméletének fejlődése és letisztult fogalmi rendszere következtében számos stacionárius egyensúlyi közgazdasági modellt valamilyen nem egyensúlyi dinamikából származtatni, mára majdnem rutinfeladattá lett. Komoly haladó egyetemi kurzusokon ezek rendkívül érdekes gyakorlatok lehetnek. Természetesen a staci- 
onárius Neumann-modell sem kerülhette el (bal)sorsát; az instabil nyeregponti egyensúlyi állapota sok kutató fantáziáját mozgatta meg, többnyire közgazdasági szempontból, érdektelen körítéssel. Neumann azért nem vizsgálta modelljének stabilitását, mert rendszere skálafüggetlen: jószágok termelése jószágok által ad infinitum, és ezért nem korlátozott. A lakatosi értelemben vett továbblépést, azaz a fogalmi dinamikán keresztül adott, szervesen a tőkés gazdaság lényegéből, a dinamikus profitfüggvényből kiinduló értelmezését azonban csak jóval később, Goodwin (1989) kitűnő tanulmányában találjuk meg.

Neumann János növekedési modellje - csakúgy, mint Cassel vagy Schlesinger modelljei - abszolút távol tartotta magát a hasznossági iskola tételeitől, a közgazdaság-tudomány fejlödésében játszott szerepe egy külön fejezetet érdemel. Bár megítélése, különösen az amerikai matematikus közgazdászok körében, ma sem egyértelmü, ha csak azt tekintjük, hogy Blinder meg sem említi tanulmányában a 20. században elért legnagyobb közgazdasági eredmények között, és az amerikai tankönyvekböl is kiszorította a jevonsi hasznosságon és önérdeken alapuló liberális gazdasági ideológia. Távol-Keleten viszont, ahol a konfuciánius tanok - az erőteljes amerikai befolyás ellenére is - gátat szabtak a szélsőséges utilitárius benthami liberális nézetek terjedésének, a neumanni örökség áll a modern közgazdaságtan középpontjában, azzal együtt, hogy - mint tudjuk - az eredeti Neumannmodell egy tiszta matematikai modell társadalomfilozófiai háttér nélkül. Gondoljunk csak Yasui, Okishio, Ichimura és Morishima, valamint az őket követő kitűnő japán növekedési iskola (Murakami, Nikaido, Negishi és Tsukui) munkásságára.

\section{Hivatkozások}

Bentham, J. (1776): An Introduction to the Principles of Morals and Legislation. Clarendon Press, Oxford. Blaug, M. (1978): Economic Theory in Retrospect. (3rd ed.) Cambridge University Press, Cambridge.

Blaug, M. (1998): The Problem with Formalism. Challange, Vol. 41, május-jnius, 11-45.

Blinder, A. S. (1999): Economics becomes a science - or does it? Megjelent: Bearn, A. (szerk.): Useful Knowledge: The American Philosophical Society Millennium Program, Philadelphia: American Philosophical Society.

Bowley, M. (1973): Studies in the History of Economic Thought Before 1870. Macmillan, London.

Cass, D. (1965): Optimum Growth in an Aggregate Model of Capital Accumulation. Review of Economic Studies, július, 233-240.

Champernowne, D. G. (1945-1946): A Note on J. v. Neumann's Article on A model of Economic Equilibrium. Review of Economic Studies, 13, 10-18.

Domar, E. (1946): Capital Expansion, Rate of Growth, and Employment. Econometrica, Vol. 14., 137-147.

Domar, E. (1957): Essays in the Theory of Economic Growth. Oxford University Press, Oxford.

Dore, M. - Chakravarty, S. - Goodwin, R. H. (1989): John von Neumann and Modern Economics. Clarendon Press, Oxford.

Dorfmann, R. - Samuelson, P. A. - Solow, R. (1958): Linear Programming and Economic Analysis. McGraw-Hill, New York.

Frisch, R. (1932): New Methods of Measuring Marginal Utility. Verlag von J. C. B. Mohr, Tübingen.

Frisch, R. (1974): Kvantitatív és dinamikus közgazdaságtan (Válogatott tanulmányok). Közgazdasági és Jogi Könyvkiadó, Budapest.

Georgescu-Roegen, N. (1971): The Entropy Law and the Economic Process. University of Alabama, Distinguished Lecture Series No. 1.

Gödel, K. (1931): Über formal unentscheidbare Sätze der Principia Mathematica und verwandter Systeme. Monatshefte für Mathematik und Physik, Vol. 38., S. 173-198.

Gödel, K. (1940): The Consistency of the Axiom of Choice and of the Generalized Continuum Hypothesis with the Axioms of Set Theory. Princeton University Press, Princeton, NJ. 
Goodwin, R. M. (1989): Swinging Along the Autostrada: Cyclical Fluctuations along the von Neumann Ray. In John von Neumann and Modern Economics, ed. by Dore, M. - Chakravarty, S. - Goodwin, R. Clarendon Press, Oxford.

Haavelmo, T. M. (1943): The Statistical Implications of a System of Simultaneous Equations. Econometrica, Vol. 11., 1-12.

Haavelmo, T. M. (1944): The Probability Approach in Econometrics. Supplement to Econometrica, Vol. 12., $1-115$.

Haavelmo, T. M. (1960): A Study in the Theory of Investment. University of Chicago Press, Chicago.

Haavelmo, T. M. (1997): Nobel Lecture. American Economic Review, december, 13-15. Harrod. R. F. (1930): Notes on Supply. The Economic Journal, Vol. 40., No. 158. 232-241.

Harrod, R. F. (1931): The Law of Decreasing Costs. The Economic Journal, Vol. 41., No. 164, 566-576.

Harrod, R. F. (1936): The Trade Cycle: An Essay. Clarendon Press, Oxford.

Harrod, R. F. (1939): An essay in dynamic theory. Economic Journal, Vol. 49., 13-33. Magyarul: Egy esszé a dinamikus elméletről. Megjelent: Szakolczai György (szerk.) (1963), 169-192. o.

Harrod, R. F. (1972): John Maynard Keynes. Peguin Books, Harmondsworth.

Harrod, R. F. (1973): Economic Dynamics, Macmillan, London.

Harsányi János (1983): Mathematics, the Empirical Fact, and Logical Necessity. Erkenntnis, 19, 167-192.

Hawking, S. W. (1998): Az idö rövid története. Talentum, Budapest.

Hawking, S. W. - Penrose, R. (1999): A tér és az idö természete. Talentum, Budapest.

Hicks, J. R.(1976): Revolutions in economics. Megjelent: Spiro J. Latsis (szerk.): Methods and Appraisal in Economics. Cambridge University Press, Cambridge, 217-218.

Hilbert, D. (1902): Mathematical Problems. Lecture delivered before the International Congress of Mathematicians at Paris in 1900, Bulletin of the American Mathematical Society, 8, 437-479.

Jevons, W. S. (1874/1924): The Theory of Political Economy. Macmillan, London.

Kemeny, J. G. - Morgenstern, O. - Thompson, G. L. (1956): A generalization of the von Neumann model of an expanding economy. Econometrica, Vol. 24., 115-135.

Keynes, J. M. (1930): Treatise on Money (2 vols). Macmillan, London.

Keynes, J. M. (1936): The General Theory of Eployment, Interest, and Money. Harcourt, New York. Magyarul: A foglalkoztatás, a kamat és a pénz általános elmélete. Közgazdasági és Jogi Könyvkiadó, Budapest.

Koopmans, T. C. (1963): On the Concept of Optimal Economic Growth. Cowles Foundation Discussion paper, december.

Koopmans, T. C. (1965): On the Concept of Optimal Economic Growth. Pontificiae Academiae Scientiarum Scripta Varia.

Kuhn, Th. S. (1984 [1970]): A tudományos forradalmak szerkezete. Gondolat, Budapest.

Lakatos Imre (1976/1981): Proofs and Refutations, The Logic of Mathematical Discovery. Cambridge University Press, Cambridge. Magyarul: Lakatos Imre (1981): Bizonyítások és cáfolatok. A matematikai felfedezés logikája. Gondolat, Budapest.

Ljapunov, A. (1907): Probleme general de la stabilite du movement. Annales de Toulouse, 9, 2.

Mátyás Antal (1999): A korai közgazdaságtan története. Aula Kiadó, Budapest.

Mátyás Antal (1999): A modern közgazdaságtan története. Aula Kiadó, Budapest.

Mead, J. E. (1937): A Simplified Model of Mr. Keynes' System. Review of Economic Studies, IV, 98-107.

Medawar, P. (1974): Hypothesis and imagination. Megjelent: Schilpp, P. A. (szerk.): The Philosophy of Karl Popper. Book 1. Open Court Publishing, La Salle, IL, 274-291.

Mill, J. S. (1844): Essays on Some Unsettled Questions of Political Economy. John W. Parker, London.

Mirowski, Ph. (1984): Physics and the 'marginalist revolution'. Cambridge Journal of Economics, 8, 361-379. Magyarul: A fizika és a „marginális forradalom”. Megjelent: Madarász (szerk.) (2000).

Moore, H. L. (1914): Economic Cycles: Their Law and Cause. Macmillan, New York.

Morgenstern, O. (1976): The Collaboration Between Oskar Mongenstern and John von Neumann on the Theory of Games. Journal of Economic Literature, Vol. 14., 805-816. Academy of Sciences, U.S.A., $36,48-49$.

Neumann János (1945): A Model of General Economic Equilibrium. (Translated into English by C. Morgenstern.) Review of. Economic Studies, 13, 1-9.

Neumann János (1955): Methods in the Physical Sciences. In: Leary, L. (ed.): The Unity of Knowledge. Magyarul: Neumann János válogatott tanulmányai. Gondolat, 1977, Budapest.

Neumann János (1965): Válogatott elöadások és tanulmányok. Közgazdasági és Jogi Könyvkiadó, Budapest. 
Pareto, V. (1896): Course d'economie politique. Rouge, Lausanne.

Pareto, V. (1909): Manuel d'economie politique. Giard, Párizs.

Phelps, E. (1961): The Golden Rule of Accumulation, A Fabel for Growthmen. American Economic Review, 51, 638-643. Magyarul: Szakolczai (1967).

Phelps, E. (1969): A Note on Short-Run Employment and Real Wage Rate under Competitive Commodity Markets. International Economic Review, Vol. 10., No. 2., 220-232. o.

Pontryagin, L. Sz. - Boltyanszkij, V. G. - Gamkrelidze, R. V. - Miscsenko, J. F. (1968): Optimális folyamatok elmélete. Müszaki Könyvkiadó, Budapest.

Punzo, L. F. (1989): Von Neumann and Karl Menger's Mathematical Colloquium, in John von Neumann and Modern Economics, ed. by M. Dore, M. - Chakravarty, S. - Goodwin, R. M., Clarendon Press, Oxford.

Punzo, L. (1991): The School of Mathematical Formalism and the Viennese Circle of Mathematical Economists. Journal of the History of Economic Thought, 13, 1-18.

Ramsey, F. P. (1927): A contribution to the theory of taxation Economic Journal, 37, 47-61.

Ramsey, F. P.(1928): A mathematical theory of saving. Economic Journal, 38, 543-559.

Samuelson, P. A. (1937): Some Aspects of the Pure Theory of Capital. Quarterly Journal of Economics, Vol. 51, No. 3. 469-496.

Samuelson, P. A. (1939): A Synthesis of the Principle of Acceleration and the Multiplier. Journal of Political Economy, 47, 786-787.

Samuelson, P. A. (1943): Dynamics, Statics, and the Stationary States. Review of Economics and Statistics, Vol. 25., 58-68.

Samuelson, P. A. (1947): Foundations of Economic Analysis. Harvard University Press, Cambridge, MA.

Samuelson, P. A. (1958): An Exact Consumption - Loan Model of Interest with or without the Social Contrivance of Money. The Journal of Political Economy, Vol. 66. No. 6., 1467-1482.

Samuelson, P. A. (1970): Economics. McGraw-Hill, New York.

Samuelson, P. A., (1989): A Revisionist View of Von Neumann's Growth Model, in John Von Neumann and Modem Economics, ed. by Dore, M. - Chakravarty, S. - Goodwin, R. M., Clarendon Press, Oxford.

Say, J. B. (1803): Traite d’economiepolitique. Deterville, Párizs .

Schumpeter, J. A. (1939): Business Cycles. McGraw-Hill, New York.

Simonyi András (1996): A Hilbert-program és Gödel nemteljességi tételei. Magyar Filozófiai Szemle, 6. sz.

Singh, S. (1997): Fermat's Enigma. Walker and Company, New York, Magyarul: A nagy Fermat sejtés. Park Könyvkiadó, 1999, Budapest.

Sismondi, J. C. L. (1819): Nouveaux principes d’économié Politique. Delaunay, Párizs.

Slutsky, E. (1915): Sulla teoria del bilancio del consumatore. Giornale degli Economisti, 51, 19-23.

Slutzky, E. (1937): The Summation of Random Causes as the Source of Cyclic Processes. Econometrica, Vol. 5., $105-146$.

Smith, A. (1776): The Wealth of Nations. Magyarul: Adam Smith: A nemzetek gazdagsága. Kossuth Könyvkiadó, 1992, Budapest.

Snyder, L. J. (1997): The Mill-Whewell Debate: Much Ado about Induction. Perspectives on Science, 5., 159-198.

The New Palgrave: A Dictionary of Economics (1987). Szerk.: J. Eatwell, J. - Milgate, M. - Newman, P. McMillan Press, London.

Theiss Ede (1930): Az áralakulás, termelés és jövedelemelosztás matematikai elmélete. Királyi Magyar Egyetemi Nyomda, 96.

Theiss Ede (1932): Time and Capitalistic Production. Journal of Political Economy, Vol. XL, No. 4., 513-531.

Theiss Ede (1932): Az időmozzanat az egzakt közgazdaságtanban. Közgazdasági Szemle, 12, 3-40.

Theiss Ede (1935): Dynamics of Saving and Investment. Econometrica, Vol. 3., 213-224.

Tsukui, J. - Murakami, Y. (1979): Turnpike optimality in input-output systems (Theory and application for planning). North-Holland, Amszterdam.

Tsuru, S. (1964): Survey of Economic Research in Postwar Japan. American Economic Review, June Supplement, 81-101.

Ulam, S. - Neumann János (1947): On Combination of Stochastic and Deterministic Processes. Bulletin of the American Mathematical Society, Vol. 53., 1120. 
Walras, L. (1874). Elements d'economie politique pure. L. Corbaz, Laussane. William Jaffe (trans.) Elements of pure economics, Richard D. Irwin. Homewood, IL.

Weintraub, E. R. (2002): How Economics Became Mathematical Science. Duke University Press, Durham, NC.

Weintraub, E. R. - Mirowski, G. (1994): The Pure and the Applied: Bourbakism Comes to Mathematical Economics. Science in Context, No. 2., 245-272.

Wicksell, K. (1907): Krisernas gata. Statekonomisk Tidskrift, Oslo, Trans. By C. G. Uhr as The enigma of business cycles. International Economic Papers (1953), 3, 58-74.

Wicksteed, P. H. (1945): The Common Sense of Political Economy. (Első kiadás: 1910.) Routledge, London. Wittgeinstein, L. (1918): Tractatus Logico-Philosophicus. Wien. Magyarul: Logikai-filozófiai értekezés. Akadémiai Kiadó, 1963, Budapest.

Zalai Ernő (1999): A közgazdaságtan metodológiájáról és a matematikai közgazdaságtanról a Neumannmodell ürügyén. Közgazdasági Szemle, 7-8., 1-36. 